\title{
LOS DIOSES LARES EN LA HISPANIA ROMANA *
}

\author{
M. ${ }^{a}$ ISABEL PORTELA FILGUEIRAS \\ Instituto Español de Arqueología. C. S. I. C.
}

\begin{abstract}
Los Lares se encuentran entre las divinidades que tuvieron una mayor aceptación en la Hispania romana. La finalidad del presente artículo es realizar una puesta al día de la bibliografía existente sobre el tema y recopilar toda la evidencia material de la que disponemos.
\end{abstract}

The Lares were some of the most beloved and worshipped deities in Hispania. This paper tries to give an up-to-date bibliography and to collect all the material evidence we have on this subject.

Los Lares fueron las divinidades que, junto con Júpiter, tuvieron una mayor aceptación en el Noroeste peninsular. La densidad de su culto en España respecto al resto del Imperio romano nos llamó la atención y decidimos adentrarnos en el estudio del mismo.

Nuestra finalidad es la de realizar una puesta al día del material existente. Las obras que tenemos resultan muy parciales, falta la gran obra de conjunto que analice a fondo todos los aspectos de este culto tan importante en la Península.

La pretensión de este trabajo ha sido más que la realización de grandes descubrimientos y la proposición de hipótesis brillantes, la recopilación del material del que disponemos.

\section{EL CULTO A LOS LARES EN LA RELIGION ROMANA}

Cualquiera que sea el origen de los dioses Lares, éstos están documentados desde época muy antigua como protectores de los campos, $y$, especialmente, como divinidades domésticas y de la familia. En cualquier caso, estos documentos presentan su nombre siempre en singular como Lar familiaris.

La prueba más evidente del carácter campestre de los Lares en su origen es la institución de un culto en honor de los Lares Compitales; cuando en los compita campestres se elevaron sacella en honor de los Lares Compitales, el número de éstos se duplicó.

* Este trabajo es un extracto de la Memoria de Licenciatura que, bajo la dirección del Prof. D. Antonio Blanco Freijeiro, Catedrático de Arqueología de la Universidad Complutense de Madrid, fue leída en esta Universidad en junio de 1982. Tengo que expresar mi especial agradecimiento al Dr. Javier Arce, sin cuya ayuda y orientación no habría sido posible la realización del presente trabajo. 
La división de Roma en vici, atribuida a Servio Tulio, fue sancionada por este culto que se convirtió en una gran fiesta móvil, celebrada durante los días que seguían a las Saturnalia. La religión de los Lares Compitales fue importada del campo y simplemente adaptada a las necesidades de la vida urbana.

Igual que en cada casa no se veneraba más que un solo Lar, como el caso más frecuente en los compita rurales era el de dos caminos cortándose en ángulo recto, los Lares eran dos. La pluralidad de la idea de los Lares parece derivada de la veneración de los Lares de las encrucijadas, antes de ser consagrada por su confusión con los Penates.

En el estudio de la evolución del culto a los Lares se aprecian dos etapas: una primera que terminará con la República, en la que los Lares conservan generalmente, incluso en las manifestaciones de la religión oficial, el carácter familiar y rústico que es el de sus orígenes; la segunda etapa se inicia con la reforma religiosa llevada a cabo por Augusto.

Como resultado de la reforma, las antiguas divinidades de las encrucijadas, los Lares, fueron convertidos en Lares Augusti. De esta forma, un ritual popular se centró en el emperador y su familia sin convertirse abiertamente en el culto del gobernante.

La creencia en los Lares como espíritus protectores y bienhechores estaba tan fuertemente arraigada en la conciencia religiosa del pueblo romano que en muchas zonas sobrevivió a la desaparición del sistema religioso del cual había formado parte en su origen.

La prueba de que el culto doméstico persistió hasta el final del paganismo e incluso en épocas posteriores, nos la proporcionan los ataques de los autores cristianos, que tienen mayor fuerza porque no derivan de fuentes literarias, sino que relatan directamente los hechos que se estaban produciendo en su época.

La tenacidad y la fuerza del culto doméstico romano estaban condicionadas por su adecuación al antiguo espíritu romano. Con el paso del tiempo se produjeron cambios y adiciones, pero eran sólo aspectos externos y poco importantes; el corazón y el centro de este culto permanecieron inalterables.

El golpe definitivo al culto doméstico tuvo lugar en una fecha tan tardía como es la del año 392 d. C., por medio de un edicto del emperador Teodosio (CODEX THEODOSIANUS, Libro XVI, título 10), por el cual se prohibía la veneración de los Lares y los Penates.

\section{EL CULTO A LOS LARES EN LA HISPANIA ROMANA}

\section{A. La introducción del culto}

Antes de tratar aspectos de carácter puramente religioso tenemos que estudiar, aunque sea de forma general, el fenómeno de la romanización de la Península Ibérica y su incidencia en la penetración de la influencia religiosa romana.

Es una opinión tradicional, y prácticamente generalizada, que Hispania, o al menos una parte de ella, fue una provincia romanizada muy intensamente y desde época muy temprana.

Algunos autores como GARCIA Y BELLIDO (GARCIA Y BELLIDO, 1967, 3-29) señalan tres etapas básicas en el proceso de romanización de Hispania: un primer impulso a este proceso sería el realizado por Augusto a través de sus fundaciones; seguiría una etapa iniciada en el siglo I d. C., caracterizada fundamentalmente por la creación de fora; un tercer y último impulso sería el realizado por los emperadores flavios, a partir de la segunda mitad del siglo I d. C.

Las obras de J. M. ROLDAN nos dan un panorama muy claro de lo que fue el proceso de romanización de la Península Ibérica (ROLDAN, 1972, 77-123). Considera 
que la romanización, tal y como hoy la entendemos, y, especialmente, para la época republicana precesariana, no es una meta consciente, sino simplemente una consecuencia derivada de una causa muy simple: la explotación material de la Península debida a su gran riqueza de recursos.

El contacto de los indígenas con Roma llevó consigo un deseo de éstos de imitar las formas de vida y de cultura de un pueblo que consideraban superior.

Roma nunca intentó imponer sus formas de vida, lengua, derecho, religión, etc., a través de la fuerza. Pero era necesario un elemento que sirviera de nexo de unión entre dominadores y dominados y éste fue la civitas romana. Los romanos trataron de conseguir que los indígenas tendieran a incluirse en la organización político-cultural mediante una hábil y lenta concesión de privilegios.

Pero toda esta política de integración en el mundo romano tiene una limitación clara: el proceso de romanización sólo se realiza en las zonas privilegiadas económicamente y utilizadas como asentamiento por los romanos de forma estable.

La pieza clave en el proceso de romanización peninsular fue, sin lugar a dudas, el elemento militar, tanto en época republicana, como durante gran parte del imperio. Su papel fundamental en la romanización estriba en el hecho de que, una vez terminado su servicio en las armas, muchos soldados no regresaron a Italia, sino que permanecieron en Hispania asentándose como colonos.

Ya hemos aludido antes a la limitación que constituía la elección de asentamiento por parte de los elementos itálicos; las zonas preferidas para este asentamiento eran el valle del Guadalquivir sobre todo y después el valle medio y bajo del Ebro; siendo éstas las únicas zonas en que el elemento indígena fue arrinconado desde fecha temprana, se desarrollaron según unas directrices culturales de tipo romano.

Por último, hay que señalar la importancia de la concesión de privilegios de manera individual o colectiva. Por su nueva categoría de ciudadanos romanos o por su contacto con el mundo romano a través de su ejercicio de las armas, los elementos indígenas al volver a su lugar de asentamiento, completamente imbuidos de la cultura romana, la transmitirían a su entorno.

Incluso las regiones del Norte y Noroeste hispano se romanizaron debido a la incorporación de tropas indígenas al ejército romano, a la influencia de las tropas romanas establecidas en estas regiones de forma casi permanente y también a la importante infraestructura viaria de estas zonas peninsulares; por todos estos factores no se puede subestimar la romanización de estas regiones ni sobrevalorar la pervivencia de elementos indígenas en las mismas.

Numerosos autores como GARCIA Y BELLIDO, BLAZQUEZ, VIGIL, PALOL, LOMAS, etc., sostienen la teoría de la escasa romanización del Norte que se manifestaría claramente en la pervivencia de las antiguas estructuras indígenas.

Esta pervivencia es un hecho real, pero, ya en época flavia, tiene una importancia menor de la que se le ha venido concediendo hasta ahora. En esta época las estructuras indígenas se encontraban muy impregnadas por la influencia romana, quedando sólo algunos reductos de indigenismo en las zonas montañosas de difícil acceso.

Una vez expuestas las líneas generales de lo que fue el proceso de romanización en la Península Ibérica, nos centraremos en las diversas opiniones que hasta hoy se han expresado sobre la introducción del culto de los Lares en la Hispania romana y sobre el carácter del mismo. ALARCÂO, ETIENNE Y FABRE $(1969,213-236)$ nos señalan que, aparte de la diferente distribución geográfica, hay que tener en cuenta el contraste cronológico por lo que se refiere a la localización de los distintos tipos de Lares.

Para ellos es evidente que la introducción del culto a los Lares Augusti en la Hispania romana data del mismo Augusto, según se deduce de la inscripción que se les dedica en Itálica (CIL II 1133); entre el 14 y el 19 se realizó la inscripción de Cartago Nova (CIL Suppl. 5929) y en el 28 la de Adamuz (CIL II 2181). 
En cambio, hay que esperar hasta la época flavia o comienzos de los Antoninos para encontrar las dedicatorias de Lares con epítetos indígenas. Este escalonamiento en el tiempo nos habla de los progresos de la romanización.

La idea que hasta hoy se ha tenido sobre este culto de los Lares es la de que solamente recubre una realidad religiosa claramente céltica. Está claro que los cultos romanos arraigaron de manera más fuerte y profunda en aquellas zonas donde preexistían cultos indígenas lo suficientemente semejantes a ellos como para asimilarlos fácilmente e incluso sustituirlos. Esto sucedió con divinidades de primer orden como es el caso de Júpiter o de Marte, pero tal vez en mayor grado con divinidades de segundo plano que, por su forma de culto más sencilla y por la especialización de su función, estaban más cercanas a estos pequeños dioses locales; éste fue el caso de las Ninfas, Genii, Lares y algunas abstracciones personificadas como Tutela.

Así pues, desde el momento en que los romanos hicieron su aparición en la Península Ibérica, comenzó a producirse un proceso de identificación y sincretismo entre las divinidades indígenas y estas divinidades tan queridas y populares entre los romanos.

TRANOY, ETIENNE, FABRE y LE ROUX (1976, 102-104) distinguen dos niveles diferentes en este proceso sincrético: el primer nivel sería representado por el simple bautismo lingüístico; el segundo nivel está muy cercano al anterior y se produce con gran rapidez, consiste en unir al nombre del dios indígena latinizado el de una divinidad romana, esto es lo que se denomina interpretatio romana, que se habría producido en la época de los Flavios o a comienzos de los Antoninos.

El hecho de que las dedicatorias a los Lares con epíteto indígena y a los Lares Viales se localicen esencialmente al norte del río Duero, mientras que los epígrafes dedicados a los Lares Augusti y a los Lares romanos propiamente dichos se localizan en el resto de la Península, nos indica que se habrían asentado estas divinidades en las regiones más recientemente anexionadas por Roma y que, por tanto, estaban menos romanizadas; en ellas las pervivencias indígenas tuvieron una mayor fuerza.

Por el contrario, en el Sur y en la costa mediterránea las influencias de los distintos conquistadores habían anulado esas expresiones locales, por ello aquí tuvieron acogida los Lares más propiamente romanos.

No podemos establecer una relación sistemática entre las nociones de medio romanizado y cultos clásicos; de la misma manera no existe una equivalencia entre los cultos indígenas y los medios no romanizados o con escasa romanización. La ciudad no jugó un papel repulsivo para las divinidades indígenas.

Ya hemos señalado en páginas anteriores que los emperadores flavios dieron un fortísimo impulso al proceso de romanización en la Península. Cabe preguntarse por qué razón los Flavios que introdujeron en Córdoba el culto imperial a nivel provincial, no aplicaron la misma política respecto al culto de los Lares; ello se debería a que se dieron cuenta de que la situación de la zona Norte de la Península era, en cierta forma, especial.

Conquistada desde hacía poco, esta región seguía ocupada por tribus indígenas, ligadas a su autonomía étnica; los Flavios prefirieron una evolución lenta, permitiendo que la romanización transformara lentamente no sólo la denominación de las divinidades sino, lo que es más importante, la mentalidad de la gente.

$\mathrm{Al}$ respetar las creencia de una población indígena, se canalizaba el impulso religioso hacia la dinastía reinante y se contribuía a la propia obra de romanización. Será pues en el siglo II de nuestra era cuando la gran cantidad de monumentos epigráficos nos atestigua la romanización progresiva de los cultos indígenas.

La interpretatio romana de la que hablamos con anterioridad se vio facilitada por la costumbre de los indígenas de añadir uno o más epítetos al lado del nombre de sus divinidades. Con respecto a este fenómeno tenemos que señalar la teoría de LAMBRINO (LAMBRINO, 1965); este autor señala que si hay interpretatio es, en cierto número de casos, más indígena que romana. 
La divinidad romana llegó a veces a sustituir a la indígena, aunque nada obligó a los autóctonos a renunciar a su vocabulario religioso.

Cuando llegan los romanos a la Península, a finales del siglo III a. C., comienza el proceso sincrético entre las divinidades de los recién llegados y las de los indígenas. Pero este proceso sincrético no es apreciable más que a partir del siglo II d. C., cuando se generaliza el proceso de asociación de las divinidades y después de la sustitución de la divinidad local por la divinidad romana.

Los Lares, juntamente con Júpiter y las Ninfas constituyen puntos de apoyo fundamentales en los que Roma trataba de basar su unificación de la vida religiosa del Noroeste peninsular. La evolución de los cultos en esta región demuestra que se está todavía en una fase intermedia, ya que son dioses como Júpiter los que asumen el papel de cohesión, desempeñado en otras regiones por el culto imperial.

Dentro de este mismo contexto hay que comprender el papel de los Lares Viales que, tras haber absorbido algunas divinidades locales, tienden a ser divinidades auténticamente oficiales con la misma función que los Lares Augusti.

Es probable que esta evolución hubiera conducido ẹn última instancia a un establecimiento más profundo del culto imperial en esta zona, pero el desfase cronológico no permitió esta realización, debido a que este culto iba a tener competencia por parte del cristianismo.

De esta forma vemos que el Noroeste peninsular estuvo abierto como el resto de Hispania a la penetración religiosa de las divinidades aportadas por los conquistadores, las cuales no se encontraron con una oposición sistemática. No hubo ningún tipo de coacción por parte de Roma, sino que este proceso es una consecuencia de los múltiples contactos que se produjeron entre ambos medios: el indígena y el romano, a través de los funcionarios y soldados y por medio de los intercambios comerciales.

Pero esta difusión tuvo sus limitaciones, no sólo por el carácter real del dios invocado bajo un nombre romano, pero que es a menudo una divinidad local, sino también por la distinción creada entre los medios oficiales y el medio indígena. La razón fundamental de esta situación es la fuerza y el dinamismo de los cultos locales.

En la vida religiosa sigue predominando el mantenimiento de las tradiciones locales, a pesar de las nuevas formas adoptadas tanto en la lengua como en los monumentos.

Observamos que las divinidades romanas, después de introducirse en el teónimo junto al dios indígena, terminaron en ciertos casos por sustituirlo. Este proceso sincrético fue el resultado de la penetración lenta y progresiva de la religión romana mediante la integración política y económica del Noroeste.

Este proceso se realizó según el grado de romanización de las distintas regiones; no se puede fijar con exactitud en el tiempo ya que el mantenimiento de los dioses indígenas y su interpretatio son acontecimientos que coexisten y que nos señalan al mismo tiempo los progresos de la romanización y sus limitaciones.

\section{B. LA EVIDENCIA}

Sin duda, tanto por su volumen como por su importante aportación de datos, el tipo de evidencia más significativo es la evidencia epigráfica. Otros tipos de evidencia: la literaria, la arqueológica, etc. son escasísimos en la Hispania romana.

\section{La evidencia epigráfica.}

Hemos sistematizado este material haciendo una serie de subdivisiones atendiendo a un criterio fundamental: la naturaleza de esos Lares, es decir, si llevan un epíteto de tipo indígena o de tipo romano, si no llevan ningún epíteto, etc. 


\section{a) Lares tópicos y gentilicios.}

Los Lares son los dioses clásicos que tuvieron más éxito en el proceso de asociación entre las divinidades indígenas y las romanas. Estos Lares que hemos denominado tópicos y gentilicios constituyen un grupo de dedicatorias a Lares que aparecen acompañados por epítetos de clara raigambre indígena. Es una tarea sumamente difícil separar los Lares tópicos de los gentilicios, pero lo intentaremos (1).

Hay que diferenciar un grupo que presenta un epíteto de carácter gentilicio: la adjetivación de la deidad se relaciona en este caso con la denominación del pueblo o tribu que le rinde culto, tal es el caso de los Lares Turolici y del Lar Pemaneiecus.

Otro grupo nos presenta un epíteto relativo a un oppidum, ciudad o región. El epíteto se refiere así de algún modo al nombre geográfico de un lugar o territorio, bien sean topónimos de procedencia indígena o romana.

Por último hay que indicar la categoría que presenta dos epítetos, pero la presencia de dos adjetivaciones no latinas es poco frecuente.

La división de las tribus galaicas en numerosas colectividades adscritas a sus correspondientes castros favorece en gran modo el nacimiento de dioses protectores de recintos amurallados o de las poblaciones que en ellos vivían o se refugiaban. Cuando las armas romanas o la intensificación de los trabajos agrícolas obligaron a abandonar la protección de los muros de los castros, convirtiéndose la colectividad guerrera en pacífica asociación de señor y colonos no debió quedar en el antiguo habitat otro recuerdo del pasado que el antiguo dios protector.

Los Lares gentilicios, honrados bajo el aspecto individual y quizás más personal o bajo el aspecto colectivo, son la exposición de un culto local de una familia, de un clan o de una comunidad étnica cuyo nombre está contenido en el epíteto que acompaña al nombre del dios.

Las relaciones entre los nombres de los dioses indígenas y los nombres de grupos sociales habían sido ya señaladas por numerosos autores que se preocuparon del mundo de los castros del Noroeste, pero el problema ha sido recientemente renovado por los trabajos de M. LOURDES ALBERTOS (ALBERTOS, 1969; íd., 1975; íd., 1977).

Revisando la lista de las divinidades indígenas de la Península Ibérica, esta autora señala que los términos, nombres o epítetos de estos dioses contienen referencias étnicas y abundan en las regiones donde están ausentes las gentilidades, pero donde se encuentran las centurias. Su razonamiento se apoya esencialmente en los nombres divinos en -aecus, -aegus, -ecus, -egus.

A pesar de estas relaciones, sigue siendo difícil saber con seguridad si el nombre o el epíteto divino se refiere a un grupo social, a una familia o a un lugar preciso.

Los Lares que presentan dos epítetos en -ecus nos aclaran el proceso de asociación entre los dioses romanos y los indígenas. Un gran número de estos últimos tiene un doble nombre en un principio: Bandua Verubrigus, Reva Laraucus, etc. La asimilación se hace esencialmente al nivel del primer nombre que expresa el elemento religioso fundamental, el segundo no hace más que precisarlo en función de un lugar o de un grupo.

Detrás del Genius o del Lar se esconde uno de estos numerosos dioses del panteón indígena, cuyo papel tutelar parece el más frecuente. En algunos casos el nombre indígena ha sido conservado enteramente con la adición de un sufijo en -ecus y el dios

(1) En total los Lares que aparecen con epítetos indígenas son: TRANOY, 1981, 303 y 304; CIL II 2469; CIL II 2470; AE, 1973, 320; AE, 1974, 409; AE, 1974, 410; CIL II 2471; CIL II 431; CIL II 2472; ILER 673; CIL II 2531; CIL II 2384; ILER 861; ILER 682; ILER 680. 


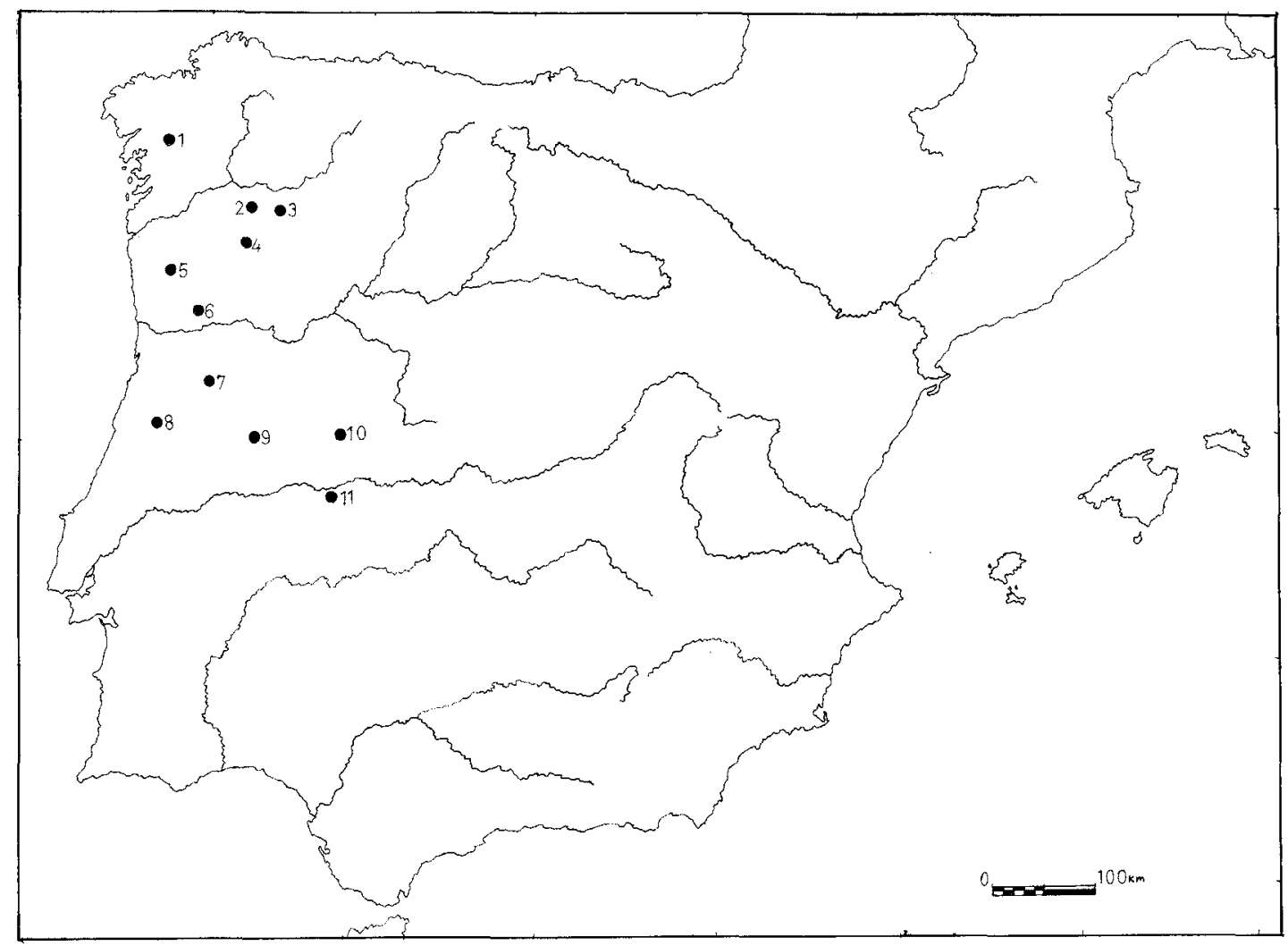

Fig. 1. Localización geográfica de los Lares Tópicos y Gentilicios.

1.--Una dedicación en S. Juan de Baños (Iria).

2.-Una dedicación en San Pedro de Reádegos (Orense).

3.-Una dedicación en Los Gozos (Orense).

4.-Cuatro dedicaciones en Aquae Flaviae (Chaves).

5.-Cuatro dedicaciones en Bracara Augusta (Braga).

6.-Una dedicación en Freixo de Numâo (Portugal).

7.-Una dedicación en Adaufé (Portugal).

8.-Una dedicación en Conimbriga (Coimbra).

9.-Una dedicación en Idanha-a-Velha (Portugal).

10.-Una dedicación en Capera (Oliva, Cáceres).

11.-Una dedicación en Villamiel (Cáceres).

romano se ha colocado en primera posición, antes del nombre indígena: Lar Circeiebaecus Proeneiaecus o Proenetiaegus y Lares Tarmucenbaeci Ceceaeci.

Ya la adopción del simple nombre romano señala el triunfo de una cierta concepción abstracta de lo divino, sin separarla definitivamente del medio indígena.

La multiplicidad de los epítetos locales para una misma divinidad romana, según S. Lambrino, demuestra que las distintas tribus de la región poseían un cierto número de divinidades distintas de nombre y unidas cada una a un rincón de tierra dado, pero muy semejantes en su esencia.

Cuando los Lares vienen de Roma, después del reinado de Augusto o, con más precisión, a comienzos del siglo II, sirvieron para unir a los distintos numina loci del lugar y pudieron a continuación aparecer fácilmente como Lares Viales, sin epítetos indígenas, haciéndose adorar en tierra lusitana como protectores de un territorio dado.

Este proceso debió desarrollarse desde la conquista del Norte de la Península (2919 a. C.); hasta el siglo II d. C. podemos encontrar dedicatorias a los Lares con epíteto 
indígena y a finales del siglo II y, sobre todo, en el siglo III, surgieron numerosas dedicatorias a los Lares Viales.

Del análisis de todo este material concluimos que las dedicaciones a Lares acompañadas de epítetos indígenas son abundantes, pero resulta imposible saber con precisión si estos epítetos se refieren a una familia, a una colectividad o a un lugar geográfico concreto.

La onomástica no resulta en este caso un elemento muy aclaratorio, pues si bien es cierto que algunos dedicantes presentan nombres romanizados pero con filiación indígena, también comprobamos que un número muy similar de estos personajes presenta una onomástica puramente romana.

La distribución geográfica resulta más clarificadora, pues la mayor parte de estos epígrafes se sitúan al norte del río Duero, esto es, en la antigua Gallaecia, y tan sólo cuatro se localizan en el territorio de la Lusitania; pero no encontramos ninguna huella de estos Lares con epítetos de tipo indígena en la Bética, la costa oriental peninsular, ni la zona de Cataluña y el valle bajo del Ebro, que eran las regiones más profunda y tempranamente romanizadas de la Península; esto prueba claramente que este tipo de Lares encubría una realidad religiosa de tipo indígena (fig. 1).

Pero no se puede menospreciar el avance de la romanización en las regiones donde se encuentran estas dedicaciones, ya que si los indígenas identificaron la divinidad romana con la local, es porque conocían los dioses romanos y comprendían las semejanzas existentes entre ambas entidades divinas.

\section{b) Lares augustos y romanos.}

Hemos incluido en este apartado no solamente los Lares Augusti, sino también aquellos Lares que, estén o no acompañados por un epíteto, parecen tener un carácter puramente romano.

Lares Augusti. Hasta ahora ninguna dedicatoria hecha a divinidades ligadas al culto imperial como los Lares Augusti, se ha descubierto en los conventus del Noroeste, contrariamente a lo que sucede en el resto de la Península Ibérica. Los dos únicos ejemplos de Genius Augusti y de Genius Caesaris se refieren solamente a la ciudad de Braga y son de datación incierta.

La rareza de las divinidades augustas y la ausencia de los Lares Augusti en estas zonas hay que ponerlas en relación con la vitalidad de los dioses indígenas en este sector de la Península.

Mientras que en las otras regiones los cultos locales habían ya sufrido transformaciones importantes por los contactos con los diferentes conquistadores que se sucedieron en la Península desde los fenicios y que prepararon el medio indígena para adoptar el culto imperial, el Noroeste conservó su personalidad propia hasta la época augustea; el fenómeno de aculturación y de sincretismo se produjo entonces a un primer nivel, el de las relaciones entre las divinidades indígenas y las divinidades clásicas. En estas condiciones el culto imperial difícilmente podía insertarse en un contexto mal preparado para recibirlo.

El culto imperial propiamente dicho, en su forma más elevada, interesó solamente a las minorías sociales más evolucionadas y que representan los cuadros romanizados de las comunidades políticas.

Merced al culto imperial y al culto de los Lares o del Genius, la sociedad indígena se transformó poco a poco; esta transformación, importante para la romanización de amplias zonas de Lusitania y de la Tarraconense, se puso en movimiento a gran escala con la dinastía flavia.

Existe todavía una oposición social entre un culto organizado en el marco de las comunidades políticas y el culto de los que están excluidos de éstas, jurídica y económicamente. 


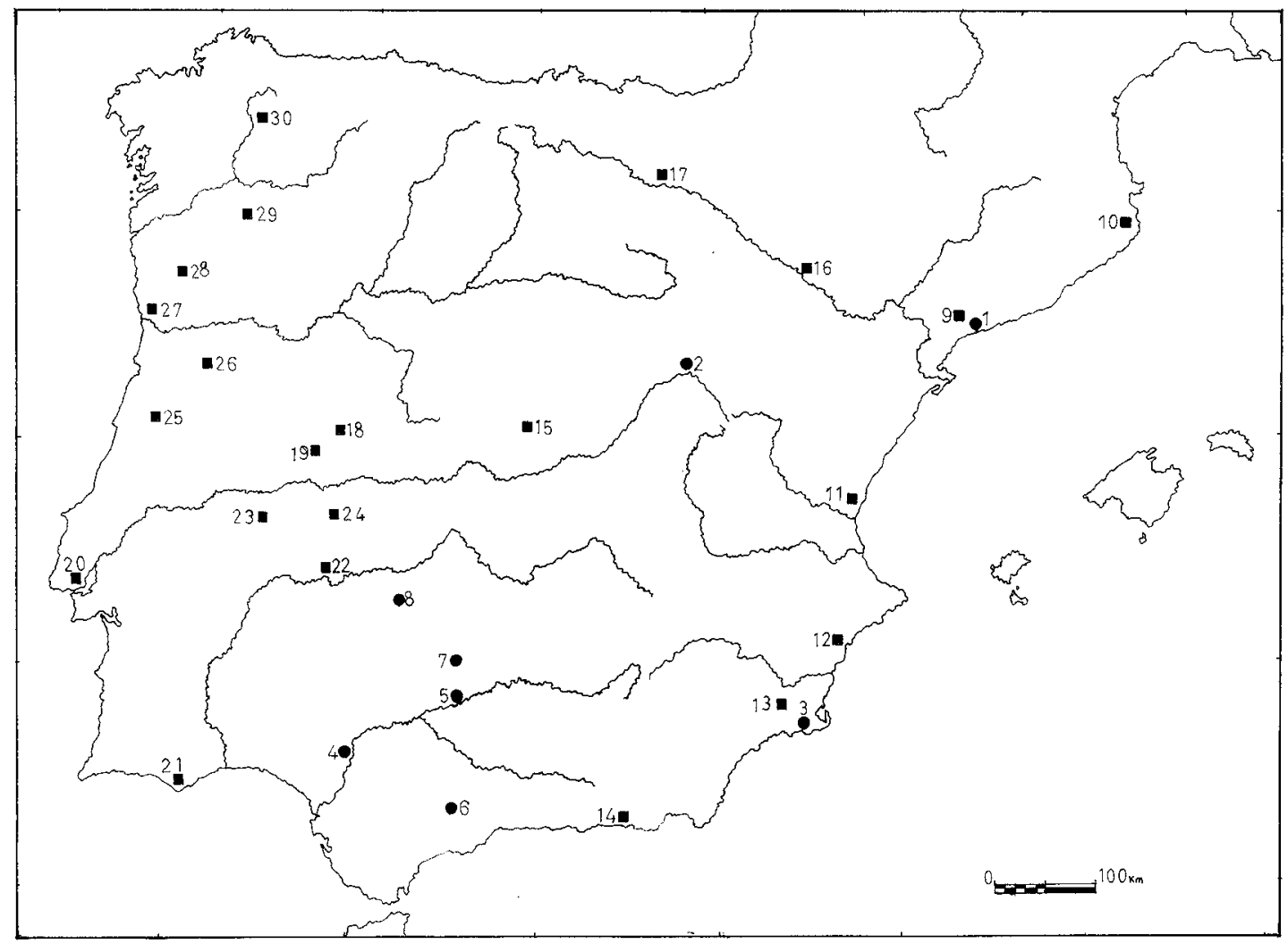

Fig. 2. Localización geográfica de los Lares Romanos y Augustos.

\section{Lares Augustos.}

Lares Romanos.

1.- Ocho dedicaciones en Tarraco (Tarragona)

2.-Una dedicación en Cabeza del Griego.

3.- Una dedicación en Cartago Nova (Cartagena).

4.- -Una dedicación en Italica.

5.- Una dedicación en Corduba (Córdoba).

6.- Una dedicación en Singilia Barba (Málaga).

7.- Una dedicación en Adamuz (Córdoba).

8. - Una dedicación en Esparragosa de la Serena (Badajoz).

9. - Cuatro dedicaciones en Tarraco (Tarragona).

10. - Una dedicación en Ampurias.

11.-Una dedicación en Saguntum (Sagunto).

12.- Una dedicación en Lucentum (Alicante).

13.-Una dedicación en la Sierra de Portman (Cartagena).

14.-Una dedicación en Abdera (Adra).

15.-Una dedicación en Villamanta (Madrid).

16. - Una dedicación en Caesaraugusta (Zaragoza).

17.- Una dedicación en Laguardia (Alava).

18.-Dos dedicaciones en Capera (Oliva, Cáceres).

19.- Una dedicación en Ibahernando (Cáceres).

20. - Una dedicación en Olisipo (Lisboa).

21.-Una dedicación en Ossonoba (Faro, Portugal).

22. - Una dedicación en Emerita Augusta (Mérida).

23. - Dos dedicaciones en Valencia de Alcántara (Cáceres).

24. - Una dedicación en Norba (Cáceres).

25.-Tres dedicaciones en Conimbriga (Coimbra).

26.--Una dedicación en Viseu (Portugal).

27. - Una dedicación en Porto (Portugal).

28.- Una dedicación en Penafiel (Portugal).

29. - Una dedicación en Civitatis Limicorum (Nocelo da Pena)

30.-Una dedicación en Lucus Augusti (Lugo). 
Los fieles de la segunda categoría: esclavos, libertos, seviri y magistri Larum, honran esencialmente a las divinidades augustas. No están, por tanto, alejados del culto imperial y juegan también un papel en el concierto universal.

Este culto de los Lares Augusti es, para ETIENNE, FABRE, LE ROUX y TRANOY (1976, 102-104), una transposición de cultos indígenas tópicos, ya que responde a la costumbre ancestral del genio tutelar de la tribu.

Estas divinidades augustas tienen además un carácter doméstico y familiar. En estos dioses que protegen al augusto, los indígenas romanizados encontraron como un eco de sus creencias, antiguas y siempre vivas, en divinidades protectoras del individuo y de la comunidad política y social; así las costumbres de la religión privada son trasladadas también al culto público.

Fundado por Augusto, este culto de los Lares Augusti se benefició de la restauración flavia. Permitió a las clases inferiores, esencialmente a los libertos, expresar su adhesión al soberano. Es digno de mención el hecho de que, a partir de Trajano, los seviri son, al mismo tiempo, magistri Larum augustorum augustales, y que un liberto, L. Flavius Chrysogonus, debe contarse entre ellos.

Lares romanos.-Dentro de este apartado incluimos no sólo las inscripciones que presentan a los Lares sin ningún epíteto, sino también un grupo de Lares que consideramos como romanos debido a los epítetos que lo acompañan o a las divinidades que aparecen junto a ellos en las dedicaciones.

Algunos de los ejemplos de estos Lares romanos son: Lares publici, Lares patrii, Lares Aquites, Lares Marini, Lares Callaeciarum, etc.

ALARCÂO, ETIENNE y FABRE $(1969,213-236)$ nos dicen que es sobre todo en las provincias donde el concepto de Lares o de Penates, en un principio preciso en la mentalidad romana, tomó, acompañado del epíteto patrii, la acepción más amplia, más vaga, de divinidad protectora, y se acercó a conceptos como Genius, Tutela, Fortuna, Numen; este hecho se deriva de la inadecuación del vocabulario romano a los diversos panteones indígenas.

Por lo que se refiere a la onomástica de las dedicaciones a los Lares romanos y a los Lares Augusti, el nombre que llevan algunos de los dedicantes de estos epígrafes, así como el epíteto que califica algunas de las ciudades en las que han aparecido, como Aquae Flaviae, que destaca por el gran número de inscripciones encontradas en ella, no pueden más que reforzar el lazo que existe entre las gentes del Noroeste y la dinastía flavia, pero el lazo es discreto.

En Conimbriga ni el Genius ni los Lares son llamados augustos, sino genio de la ciudad o Lares de la ciudad, mientras que en Itálica se encuentra un magister Larum Augustorum que lo es también del Genius Caesaris Augusti.

Entre los fieles se encuentra una mayoría de ciudadanos de origen humilde: esclavos, libertos; sobre todo, seviri y magistri Larum que no tienen todavía la capacidad jurídica de entrar en los cuadros de la ciudadanía romana y, por tanto, de ocupar un puesto de flamen; pero no están, sin embargo, alejados del culto imperial y juegan su papel en el mismo.

De las diecisiete inscripciones en que se alude a un culto de los Lares augustos, la mayor parte menciona a personajes que ostentan el cargo de Magister Larum; otra de ellas está dedicada por unos decuriones Larum y procede de Tarraco; en otra, procedente de Itálica, se habla de un magister Larum Augustorum que lo es al mismo tiempo del Genius Caesaris Augusti.

Por lo que se refiere a la onomástica propiamente dicha que aparece en estos testimonios, presenta unos nombres claramente romanos, con los tria nomina presentes en la mayor parte de los casos. En algunas ocasiones se especifica que se trata de libertos. Incluso en una inscripción de Tarraco (CIL II 4297) un liberto aparece como magister Larum augustalis. 
De los catorce epígrafes en que se hace alusión al culto de los Lares puramente romanos, se aprecia ya que los casos en que aparecen los tria nomina son muy escasos, siendo lo más frecuente la aparición de un solo nombre: Telesphor.. y Plate, Faustus, etcétera.

Podría pensarse que en la mayor parte de los casos se trata de libertos, de hecho en algunas ocasiones tenemos testimonios totalmente seguros; por ejemplo, en la inscripción de Abdera (CIL II 1980) los dedicantes son Suavis libertus y Faustus vilicus.

Si estudiamos la distribución geográfica de los epígrafes, vemos que el culto de los Lares Augusti floreció en la Tarraconense: nueve inscripciones en total, siete de las cuales son de Tarraco (CIL II 4302; 4304; 4307; 4309; 4293; 4297; AE, 1929, 231); una de Cabeza del Griego (CIL II 3113) y una de Cartago Nova (CIL, Suppl. 5929).

En la Bética hay también una representación importante, con cinco epígrafes en total: en Singilia Barba, Itálica, Corduba, Adamuz y Esparragosa (CIL II 2013; 1133; 2233; 2181; ILER, 597). Para confirmar que excepcionalmente este culto alcanzó la Lusitania, sólo una inscripción lo menciona en Emérita.

El culto de los Lares romanos conoce adeptos dos veces en Capera, una en Olisipo, una en Viseu, una en Ossonoba, una en Valencia de Alcántara y una en Norba (CIL II 816; 817; 174; 404; 5135. ZEPHYRUS, 1967, p. 98, n. ${ }^{\circ} 10$; id., p. 93, n. ${ }^{\circ} 7$ ).

En la Tarraconense tenemos también la mayor densidad de dedicaciones: cuatro en Tarraco, una en Emporiae, una en Sagunto, una en Toledo, una en Lucentum y una en la Sierra de Portmann (CIL II 4082; 4306; 6106; AE, 1900, 118; HAEp. 1574; CIL II 3081; 3563; AE, 1953, 17). En la Bética solamente tenemos una, la de Abdera (CIL II 1980).

El reparto geográfico demuestra que, por lo que respecta al culto de los Lares Augusti, la Tarraconense y la Bética se equilibran, mientras que los testimonios recogidos en Lusitania no representan más que el $10 \%$ del conjunto de las dedicaciones.

De todo este material sacamos la conclusión clara de que el culto a los Lares más propiamente romanos y a los Lares ligados al culto imperial se localiza en las zonas más temprana e intensamente romanizadas de Hispania: la Bética y la zona de la Tarraconense (fig. 2).

En cambio, nos encontramos con que en el resto de la Península no hay huellas de estos cultos, aunque tenemos que en esta región peninsular hay zonas, como Callaecia, en donde el culto a los Lares con epíteto indígena y a los Lares Viales tiene una densidad enorme.

Los nombres de los dedicantes nos demuestran la importancia de los ciudadanos que podríamos llamar "de segunda categoría», los cuales juegan un papel muy importante en el culto de los Lares Augusti; este papel de los esclavos y libertos ya lo hemos resaltado al hablar del culto de los Lares Compitales.

\section{c) Un caso especial: los Lares Viales.}

El culto de los Lares Viales representa, con el de Júpiter, el culto romano que ha sido mejor aceptado por las poblaciones del Noroeste de la Península. La proporción importante de los Lares Viales en esta región española y su concentración en los dos conventus galaicos habían ya atraído la atención de los historiadores.

Su culto representa para algunos autores como LAMBRINO y BLAZQUEZ (LAMBRINO, 1965, 233-234; BLAZQUEZ, 1970, 63 y ss.), la última evolución de los Lares de las localidades o de la gentilidades.

Estas divinidades están muy escasamente testimoniadas con esta denominación en el resto del Imperio romano; por este motivo, su concentración en la Península Ibérica ha llevado a suponer a la mayoría de los investigadores que esta denominación latina oculta una serie de numina indígenas, que sobrevivieron en época romana e incluso pa- 


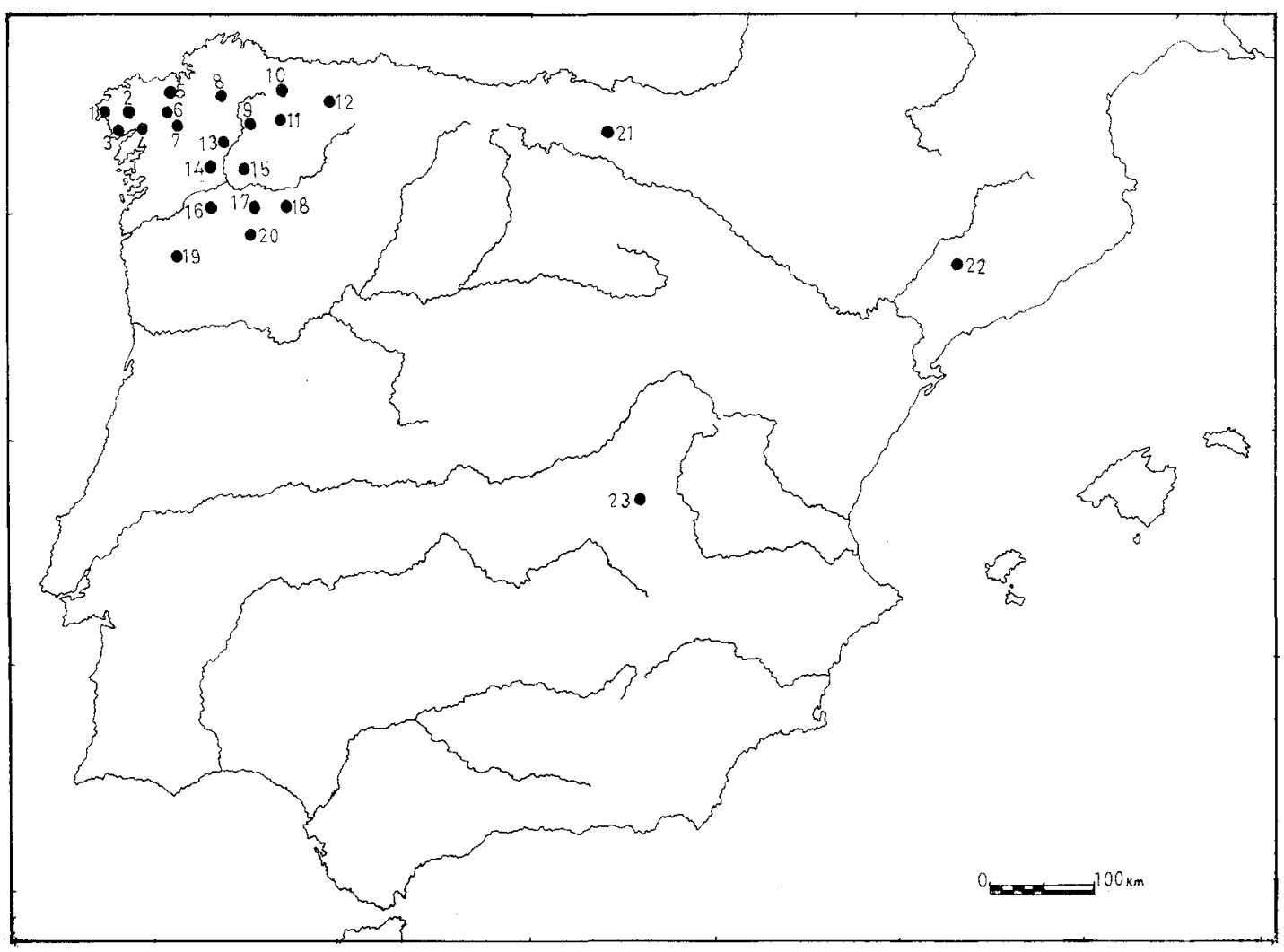

Fig. 3. Localización geográfica de los Lares Viales.

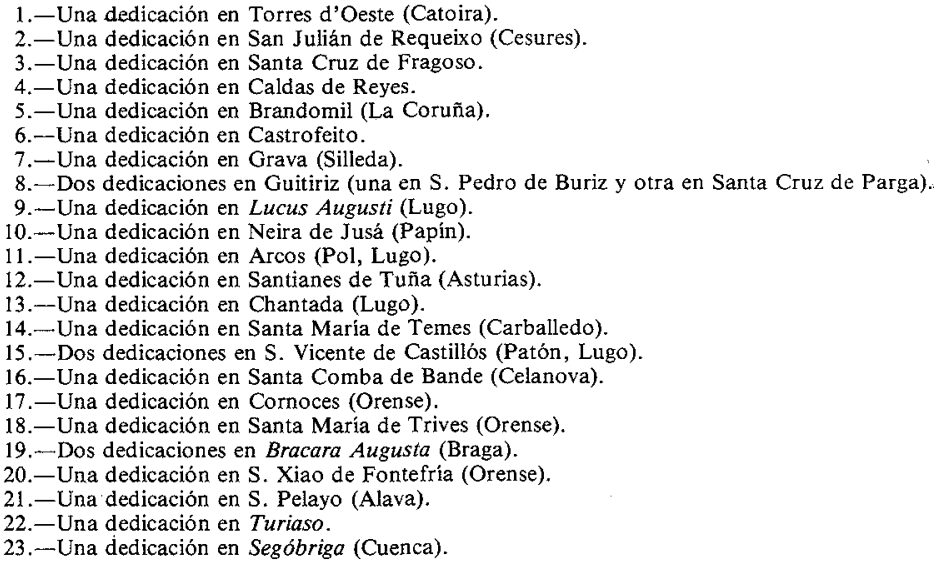

recen tener una presencia clara en épocas posteriores. Esta opinión fue expresada ya por LOPEZ CUEVILLAS y SERPA PINTO $(1934,295$ y ss.).

S. LAMBRINO afirma que los Lares como divinidades latinas llegan de Roma al Noroeste peninsular a comienzos del siglo II, y sirven como medio de unión y de asimilación con los numina loci.

Esto representaría un proceso de sincretismo entre la religión romana y la religión indígena, que se extiende entre el año 19 a. C. y finales del siglo II. Cuando ya se había concluido este proceso, en el siglo III, surgen las dedicaciones a los Lares Viales. 
F. ACUÑA CASTROVIEJO siguió sosteniendo esta misma teoría (1971, 353-357). ALARÇÂO, ETIENNE y FABRE consideran que esta forma romana de los Lares recubre una realidad religiosa y céltica, cuyo carácter bárbaro desaparece recubierto por la denominación romana. Para estos autores, por medio del culto de los Lares se pasa de una sociedad céltica a otra céltico-romana; este culto no sería más que una etapa hacia una romanización total y hacia una transformación de la mentalidad indígena.

Hay una serie de matices de tipo regional en el culto a los Lares Viales que se pueden deducir por medio de su localización geográfica. En el conventus de Braga este culto tiene una representación bastante débil: cinco altares y una inscripción en una de las caras de un cipo (CIL II 2518; AE 1973, 310; BOL. AUR. II, 1972, 309-311; CIL II 2417; IRG IV 93). En cambio, los Lares con epíteto indígenas son más numerosos.

En el conventus de Lugo el fenómeno es totalmente diferente. Aquí el culto a los Lares Viales es prácticamente idéntico en número de dedicaciones al de Júpiter, pues tenemos diecisiete altares (BOL. AUR. IX, 1979, 311-315; IRG II 9; IRG III 25; IRG III 26; A. TRANOY, 1981, 217; IRG II 8; HAEp. 1-3, 308; IRG III 23; IRPL 63; IRG II 10; IRPL 65; íd., 66; IRG III 22; CIL Suppl. 5634; IRG III 24; IRPL 64; CIL II 2572). Sin embargo están ausentes las divinidades romano-indígenas, como son los Lares con epíteto local.

En este conventus los cultos indígenas eran menos fuertes y los Lares Viales cubren a los dioses locales sin pasar por el estado intermedio de las divinidades con un tipo de denominación mixta. En estas condiciones, el papel de unificación que podía realizar Júpiter le es disputado por los Lares Viales, cuyo carácter más personal fue mejor asimilado por los Callaeci Lucenses.

Por el contrario, el dinamismo de los cultos indígenas fue un obstáculo para el éxito total de los Lares Viales entre los Callaeci Braccari, donde paradójicamente la difusión más rápida de las influencias romanas permitía el establecimiento de Júpiter que tenía suficiente fuerza para imponerse a los cultos locales.

Así, la penetración de las influencias romanas favorecía a la vez a la manifestación más clara de los cultos indígenas por la adopción de los tipos de monumentos romanos y de la lengua latina.

El culto de los Lares Viales, como el de Júpiter, ilustra la voluntad de Roma de mantener en torno a estos dioses la cohesión religiosa de los múltiples pueblos de Galicia. La dispersión de las dedicaciones es también el reflejo de la penetración bastante amplia de Roma en el interior del país.

En el conventus Asturum la actitud fue también diferente. El desarrollo de los servicios administrativos, del ejército y de las zonas mineras dio más importancia a ciertos sectores geográficos, sobre los cuales se concentraron los esfuerzos de poder. Este hecho condujo a la polarización de los testimonios culturales en estas regiones, apareciendo las zonas rurales a menudo descuidadas, en especial las zonas montañosas.

El resultado de este fenómeno es la débil proporctón de los cultos indígenas y la rareza de los Lares Viales, representándolos solamente por dos epígrafes (IRG IV 101; CIL Suppl. 5734).

Así observamos que cada conventus reaccionó a su manera ante este culto en función del proceso y del grado de penetración de las influencias romanas. En la Península Ibérica solamente hay tres inscripciones dedicadas a los Lares Viales que se localicen fuera de la región Noroeste: una en Segóbriga, otra en Turiaso y una última en Alava (AE 1903 185; CIL II 2987; ELORZA, 1972) (fig. 3).

Es aún más significativo en el estudio de esta distribución geográfica el hecho de que sólo existan cinco inscripciones dedicadas a los Lares Viales en todo el Imperio romano: una en la Dacia, en Sarmizegetusa; una en Mauritania, en Portus Magnus; una en la Galia, en Narbo, y dos en Italia, una en Falerii y otra en Roma (CIL III 1422; CIL VIII 9755; CIL XII 4320; CIL XI 3079; CIL VI 36812). 
Como se puede observar, los testimonios de culto a los Lares Viales resultan abrumadores en la Península Ibérica con respecto al resto del mundo romano.

A. TRANOY $(1981,322-324)$ señala que la distribución geográfica de este culto es significativa, ya que los Lares Viales están en relación estrecha y lógica con la red viaria del Noroeste, aunque, según este autor, el hecho de que no aparezca este tipo de dedicaciones en el resto de la red viaria peninsular demuestra que no estaba únicamente ligado a las vías.

La red viaria sirvió solamente como infraestructura a la difusión de la romanización que, en el plano religioso, se cristaliza en torno a los Lares Viales, transmitidos a través de los grandes ejes de circulación y utilizados como elemento de reagrupación de las fuerzas religiosas locales de estas regiones recientemente conquistadas.

Son quizás estas fuerzas múltiples las que se expresan en los altares de varios foci, característicos del Noroeste; en la mayoría de los casos este tipo de altares se ofrece a los Lares Viales y suelen provenir del conventus de Lugo: Arcos, Castrofeito, Parga, San Pedro de Buriz, San Vicente de Castillones (IRG II 9; TRANOY, 1981, 217; IRPL 66; íd., 65; IRPL 63; íd., 64).

Este culto, junto con el de Júpiter, representa una etapa de la asimilación y del sincretismo entre las religiones locales y la religión romana. $\mathrm{Si}$, en este aspecto, un dios como Mercurio no tuvo en Galicia y en Asturias más que un papel modesto, en cambio, Júpiter, los Lares y las Ninfas constituyen las divinidades fundamentalmente sobre las que Roma pudo apoyarse para tratar de unificar la vida religiosa del Noroeste peninsular.

La administración y el ejército fueron agentes de propagación de estos cultos, siguiendo los grandes ejes de comunicación y gracias a las dedicaciones oficiales.

La evolución de los cultos en Asturias y Galicia muestra que se está todavía en una fase intermedia en que son los dioses como Júpiter los que asumen el papel de cohesión que tiene en otras regiones el culto imperial.

En este mismo espíritu hay que situar a los Lares Viales que, después de haber absorbido a divinidades locales, tienden a ser verdaderas divinidades oficiales, comparables a los Lares Augusti. Es probable que esta evolución hubiera llevado a un establecimiento más profundo del culto imperial en estas regiones, pero el desfase cronológico no permitió la realización de este proceso, ya que este culto se vio enfrentado con el cristianismo.

Como nos sugieren LOPEZ CUEVILLAS y DE SERPA PINTO (1934, 295 y ss.) el acentuado localismo de las invocaciones a estos espíritus protectores de las vías hace sospechar fundadamente que bajo ellos yacía un numen o un grupo de númenes galaicos asimilados o suplantados completamente por dichos Lares.

De la supervivencia de su culto tenemos un testimonio evidente en un texto de San Martín Dumiense (S. MARTIN DUMIENSE, De correctione rusticorum, XVI, 4-5) que recomienda que no se enciendan luces en las encrucijadas, trivia, aludiendo de esta manera al culto que se tributaba a los Lares en los cruces de caminos.

Como vestigios más modernos de la supervivencia de este culto algunos autores consideran los cruceros y los amilladoiros, que son grupos de piedras erigidos por romeros y caminantes.

Es un hecho cierto que, de la misma manera que no hay otra región de la Península más rica en invocaciones a los Lares Viales que el Noroeste, no hay tampoco ninguna zona que cuente con tantos cruceros. Hay que destacar que su área de mayor densidad se encuentra en los territorios de los antiguos conventus Bracaraugustanus y Lucensis, es decir, en el área de mayor densidad de las dedicaciones a los Lares Viales.

Para López Cuevillas y Serpa Pinto la falta de continuidad entre los cruceros y las lápidas erigidas para honrar a los Lares puede muy bien deberse a la fuerza destructora del tiempo. 
En las obras que hemos consultado sobre la Galia, Britania, etc., no encontramos referencias a este culto de los Lares Viales. En ellas se nos habla sobre todo del culto doméstico, pero no de los dioses protectores de los caminos.

Autores como ALARCÂO, ETTIENNE y FABRE (1969, 213 y ss.), así como LOPEZ CUEVILLAS y SERPA PINTO $(1934,297)$, aseguran que la forma romana del nombre de los Lares recubre una realidad religiosa céltica.

No podemos negar de forma absoluta esta afirmación, pero resulta sorprendente el hecho de que no se encuentren dedicaciones a esta advocación de los Lares en territorios claramente célticos como la Galia o Britania.

Se ha dicho que el culto de los Lares Viales presentaría un paralelo evidente con el culto de las Matres galas, cuando son invocadas con los epítetos de biviae, triviae, quadriviae, pero no hemos encontrado este testimonio en ninguna de las obras consultadas; en todas ellas se alude a las Matres como diosas relacionadas más bien con la fecundidad, una especie de Diosas Madres. En alguna ocasión encontramos Matres invocadas bajo los epítetos anteriormente mencionados, pero se trata de ejemplos aislados que no nos permiten sacar conclusiones claras ni establecer paralelos.

Por otra parte, hay que señalar que J. C. BERMEJO BARRERA, en su estudio sobre los dioses de los caminos (1978, 77-177), analiza detenidamente las semejanzas de los Lares Viales galaicos con otras divinidades de tipo céltico como el Mercurio galo, Lug, Bran, etc., y llega a la conclusión de que ninguna de estas divinidades es el modelo de los Lares Viales galaicos, sino que éstos presentan mayor número de semejanzas con el Hermes griego.

Nos parece significativo el hecho de que este autor no encuentre similitudes entre otros Lares galaicos y los dioses célticos de los caminos.

Esto no quiere decir que no aceptemos que este culto de los Lares Viales representa una fusión clara entre la religión romana y los númenes indígenas; simplemente nos ha llamado la atención esta falta de coincidencia entre los Lares galaicos y los dioses de la Galia o de Britania, ya que muchos autores han supuesto que bajo la denominación de Lares se esconde una realidad religiosa céltica.

Habría que considerar la posibilidad de que se trate simplemente de divinidades precélticas, puesto que su carácter indígena parece indudable.

LAMBRINO $(1965,233-234)$ señala que no se puede decir que las dedicaciones a los Lares Viales no son de la misma esencia que las de los Lares tópicos y gentilicios, pretextando que los primeros representan el culto imperial que asociaba a los Lares de las encrucijadas con el Genius Augusti desde el año 7 a. C.

Si esto fuera así, como monumentos del culto al emperador no se habrían confinado en el territorio del Noroeste peninsular, el más recientemente conquistado y el menos romanizado, sino que se habrían extendido con profusión por el resto de la Península, más profundamente romanizada, pero esto no sucede así.

\section{Otros tipos de evidencia.}

Hemos reunido en un solo epígrafe los restantes tipos de material que, sobre el culto a los Lares, poseemos en la Península, porque estas muestras son muy reducidas.

Por lo que se refiere a la estatuaria, vemos que los Lares son siempre representados como figuras juveniles. Lo más corriente es que las estatuillas sean de bronce.

Se distinguen tradicionalmente dos tipos en la iconografía de los Lares: uno, que nos presenta al Lar en reposo, con un pátera en la mano derecha y una cornucopia en la izquierda, siempre con chiton y manto; algunos autores como WISSOWA han relacionado este tipo iconográfico con el Lar familiaris; el otro tipo presenta a los Lares no en reposo, sino con un movimiento suave y armonioso, que recuerda una danza; derraman el líquido de un rhyton que elevan con la mano derecha en una pátera o sítula 
que sostienen con la izquierda; a menudo visten sólo chiton; este tipo de representación se relaciona con los Lares Compitales.

Tenemos gran abudancia de estatuillas que representan Lares en la Península Ibérica, pero la mayor parte pertenecieron a colecciones privadas y por ello es muy difícil conocer su lugar de procedencia con exactitud, aunque la mayoría parecen ser importaciones itálicas.

Conocemos tan sólo cinco estatuillas que procedan con seguridad de la Península Ibérica y las vamos a estudiar a continuación (fig. 4).

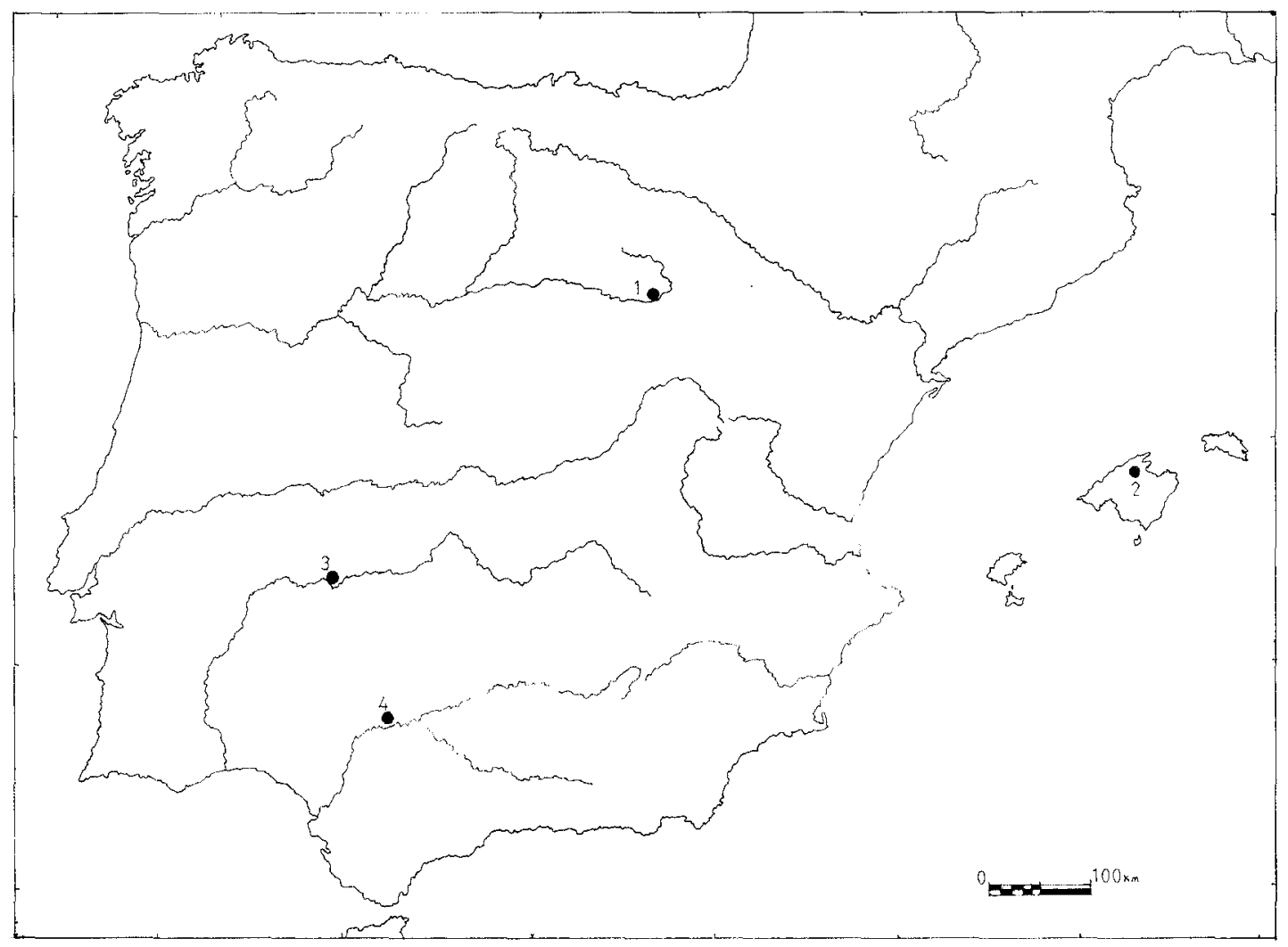

Fig. 4. Localización de las estatuillas de Lares.

1.-Almazán (Soria).

2.-Pollentia (Pollensa). Dos estatuillas.

3.--Emerita Augusta (Mérida).

4.-Lora del Río.

La primera de ellas se encuentra en el Museo Arqueológico Nacional y es el conocido Lar de Lora del Río (Sevilla) (fig. 5). Descripciones de esta figurilla se encuentran en varias publicaciones (THOUVENOT, 1927, 50-52; DEL RIVERO, 1927, 28-29), pero nos basaremos en la descripción que de ella nos hace GARCIA Y BELLIDO $\left(1949,104, \mathrm{n}^{\circ} 98\right)$.

Se trata de un bronce de pátina verdosa y concreciones terrosas, fundido en hueco. Presenta una altura de $22 \mathrm{cms}$. Es una obra de buena factura, una de las más bellas representaciones de estas divinidades que tenemos en la Península. Su cabeza va ceñida con una diadema de palmetas, atada por detrás con unas cintas cuyos largos cabos cuelgan por ambos lados hasta tocar los hombros. En la mano izquierda lleva un cuerno de 


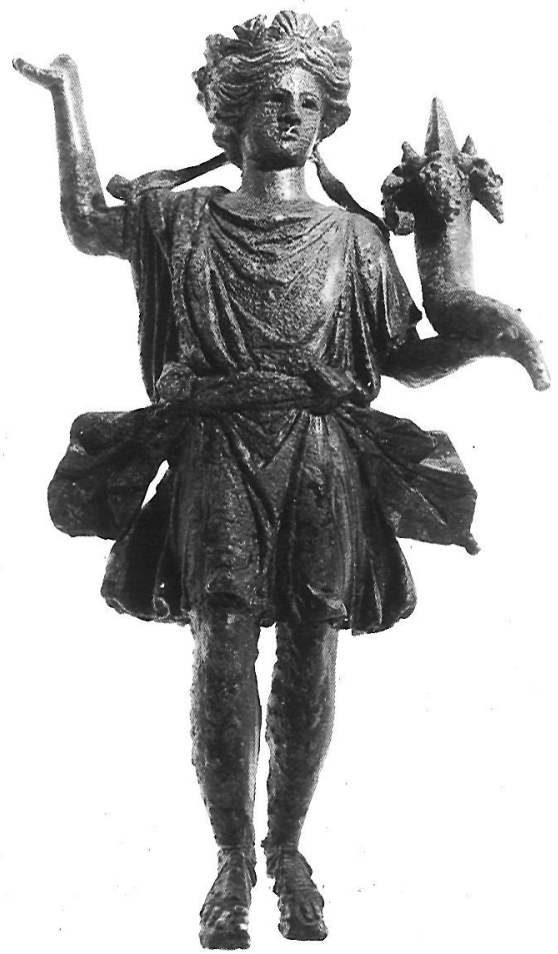

Fig. 5. Lar. Bronce. Procedente de Lora del Río. (Foto Museo Arqueológico Nacional).

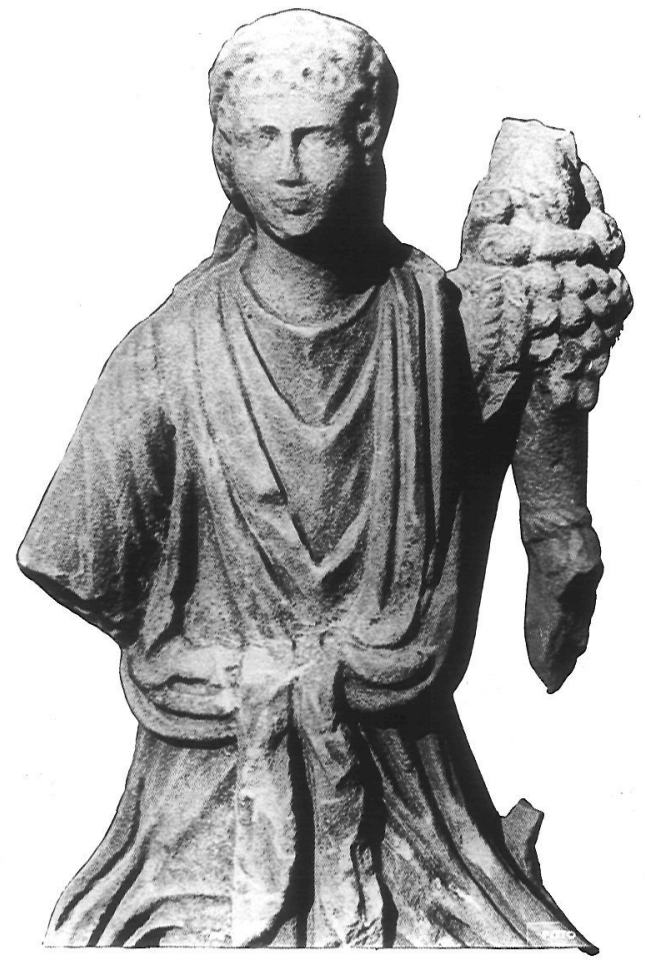

Fig. 6. - Lar. Mármol blanco. Procedente de Mérida. Museo Arqueológico Provincial de Badajoz.

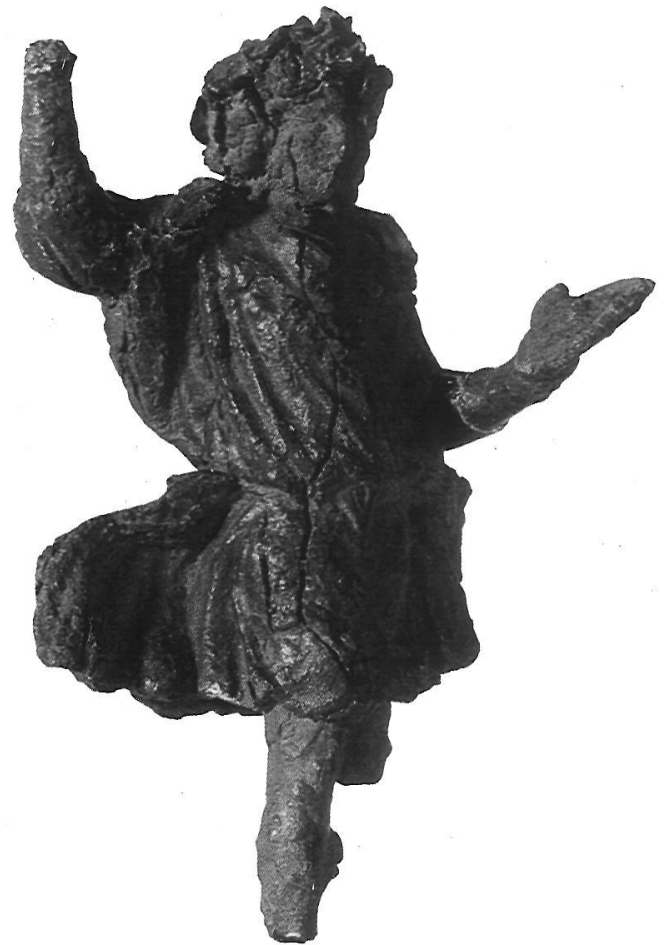

Fig. 7.-Lar. Bronce. Procedente de Pollentia. (Foto Museo Arqueológico Nacional). 


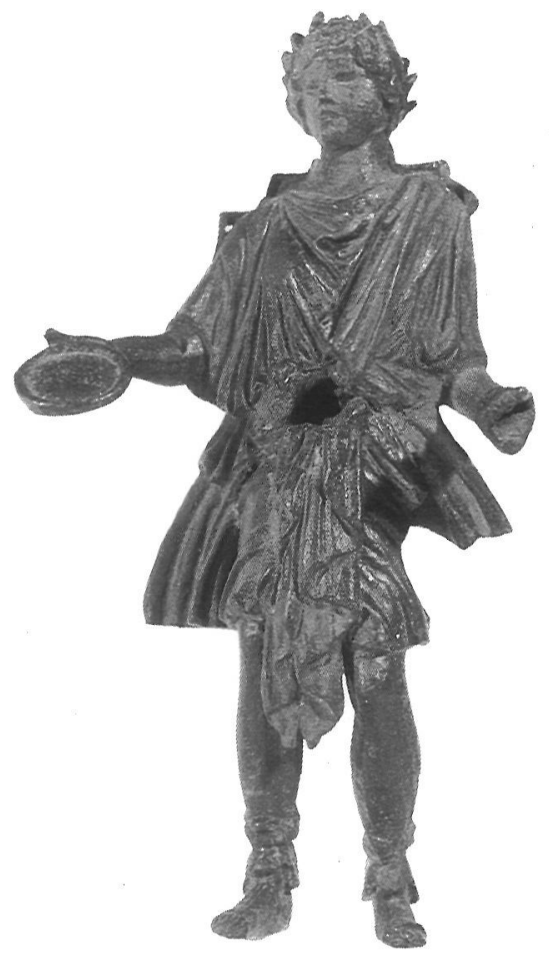

Fig. 8.-Lar. Bronce. Procedente de Pollentia. (Foto Museo Arqueológico Nacional).

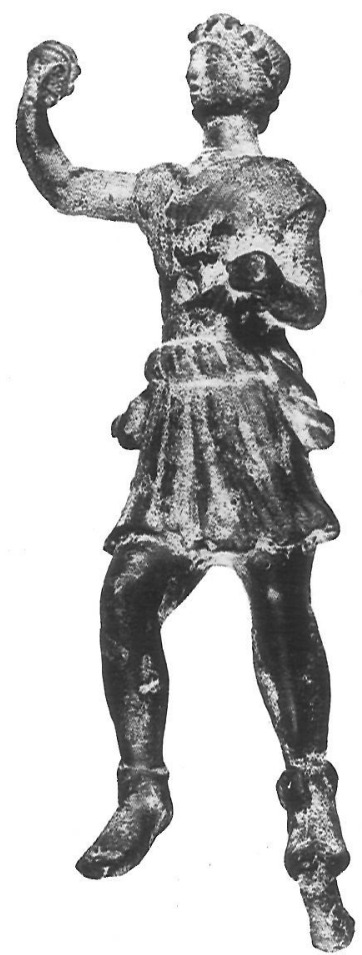

Fig. 9.-Lar. Bronce. Procedente de un campamento militar de Almazán (Soria). (Foto Museo Arqueológico Nacional).

la abundancia. En la derecha, levantada, tal vez llevase el acostumbrado rhyton, aunque no se ve huella del mismo.

Viste un corto chiton o túnica con abundantes pliegues y, sobre él, un manto que, tras cruzar el pecho y el hombro derecho se anuda a la cintura, para dejar colgando al aire sus dos cabos, de la forma que es característica en las representaciones de los Lares. Presenta un ligero movimiento, avanzando un poco la pierna derecha. Los ojos, ahora huecos, debieron llevar piedras incrustadas. Los pies calzan sandalias.

No tenemos ningún otro ejemplar que se adapte precisamente a este modelo, especialmente por lo que se refiere al brazo derecho levantado, pues la otra representación de Lar con cornucopia que conocemos tiene este brazo bajo y no levantado.

La siguiente pieza que vamos a analizar es la que se encuentra en el Museo Arqueológico Provincial de Badajoz (fig. 6). Ha sido también publicada en varias ocasiones, pero nos atendremos a la publicación más reciente, la de ALVAREZ MARTINEZ $(1975,869-872)$.

Esta figura es algo diferente de las demás no sólo por su mayor tamaño, sino también por el material en que está realizada, ya que es de mármol blanco de pátina amarillenta, procedente probablemente de las canteras de Borba-Estremoz, en Portugal. Fue hallada en las inmediaciones de Mérida. La figura sin el plinto, que tiene una elevación de 7 centímetros, alcanza una altura de 0,96 metros.

Falta todo el antebrazo derecho, que era una pieza aparte que se ajustaba en el brazo, lo cual es un elemento curioso. También falta la mano izquierda. Se trata, como siempre, de un adolescente en pie, en actitud serena y reposada, aunque sus piernas y los pliegues de la túnica denotan un leve movimiento. 
Todo el cuerpo se apoya en el tronco de un árbol colocado junto a la pierna derecha. Viste túnica corta con mangas y manto. Calza unas botas altas, sujetas con correas que dejan libres las puntas de los pies, con adorno de carátulas a la altura de los tobillos (endromides).

La escultura está bien trabajada, aunque algo más esquemática en su parte posterior. Por lo que se refiere a la cronología de la escultura José María Alvarez cree que hay una particularidad que puede dar una pista sobre su fecha de realización: el peinado. Este es muy parecido al que vemos en las efigies de Agripina, caracterizado por rizos en forma de caracolillos que rodean la frente y que se resuelven por detrás en un moño, a la altura de la nuca. Esto permitiría fechar esta estatua hacia la mitad del siglo I d. C.

Otras dos estatuillas que representan Lares proceden de Pollentia y se encuentran en el Museo Arqueológico Nacional.

La primera de ellas (fig. 7), en muy mal estado de conservación, presenta todas las características típicas de las representaciones de estas divinidades: túnica corta, manto enrollado en torno a la cintura de forma característica, cabeza ceñida por una diadema. Faltan las piernas. La mano izquierda sostiene la pátera y la derecha, que se ha perdido, levantaría el rhyton sobre la cabeza.

La otra representación procedente de Pollentia (fig. 8) presenta las mismas características, pero su estado de conservación es mucho mejor. La figura además aparece en una actitud mucho más reposada que la anterior. La mano izquierda ha desaparecido. Hay que resaltar que la pátera la lleva en la mano derecha y no en la izquierda como es usual; además ninguno de sus brazos está levantado en actitud de derramar el líquido; no sabemos lo que llevaría en la mano izquierda, ya que ha desaparecido.

Por último tenemos una estatuilla procedente de un campamento militar en Almazán (Soria) (fig. 9); parece que se puede fechar en los siglos I-II aproximadamente. Es una representación que, a primera vista, parece muy distinta de las otras por su ejecución; su movimiento es más brusco, pero parece tener todos los atributos de un Lar; la túnica corta, el manto enrollado en la cintura de forma característica, la cabeza ceñida por la diadema, aunque sin ínfulas; el brazo derecho está levantado, pero tanto la pátera como el rhyton han desaparecido.

No tenemos noticia de`que las estatuillas de Pollentia y la de Almazán hayan sido publicadas.

Hay que hacer una diferenciación en estas representaciones; el Lar de Lora del Río y el del Museo de Badajoz parecen responder al tipo iconográfico que se relaciona con el Lar familiaris, en actitud más reposada y con la cornucopia en la mano izquierda, aunque el de Lora del Río presenta la particularidad de tener levantado el brazo derecho.

El primero de los Lares de Pollentia que hemos descrito, el peor conservado, y el de Almazán, se identifican más con el tipo de representación del Lar compitalis, con un mayor movimiento, la pátera en la mano izquierda y el rhyton en la derecha que se eleva sobre su cabeza.

La segunda de las estatuillas de Pollentia parece responder también al tipo de Lar familiaris, como parece indicar su actitud reposada y el hecho de no llevar el rhyton en actitud de derramar el vino, pero no podemos asegurarlo, ya que falta el objeto que llevaba en su mano izquierda, que pudo haber sido una cornucopia.

Hay que resaltar que ninguna de las estatuillas que hemos mencionado se localiza en Galicia, sino que proceden una de Sevilla, una de Soria, una de Badajoz y dos de Mallorca.

Por lo que se refiere a los restos arquitectónicos, en la Península Ibérica es muy difícil encontrar lararia, debido a que de las construcciones romanas habitualmente nos restan solamente los cimientos y los lararia se situaban en la mitad de la pared. Nos han proporcionado noticias de un posible lararium en las proximidades de Itálica, pero es un extremo que no hemos podido comprobar. 
En un Catálogo del Museo Arqueológico de Tarragona, una publicación muy antigua de 1894, encontramos la noticia de la existencia de un altar de mármol blanco que parecía proceder de un templo a los Lares, Tutela y el Genio (CIL II 4082).

ALMAGRO $(1966,35)$ nos habla de lo que parece una evidencia importante del culto doméstico, la presencia en el jardín de una casa romana de un altar cubierto con estuco y pintado a la manera de los lararia. Dos serpientes flanquean un altar encendido sobre este templo en forma de herma.

El profesor Almagro cree que esto significa un culto cthónico de los muertos y que se trata de hecho de una herma. Pero la similitud de las serpientes y la decoración, junto con su colocación en el jardín, un lugar común en Campania para un templo, señalan su papel de vigilancia y protección más que su relación con el ritual mortuorio.

Por lo que se refiere a la evidencia literaria, carecemos de noticias directas sobre el culto de los Lares. Sólo hay un texto de ESTRABON (III, 3, 7), en que nos informa de que a los enfermos los sacaban a los caminos para que los viandantes los observaran y si habían tenido una enfermed parecida, les dieran el remedio, lo cual puede aludir a la sacralidad de los caminos y encrucijadas; pero la referencia es tan mínima que es imposible obtener una información de cierta significación a partir de la misma.

\section{Algunas notas sobre los colegios religiosos relacionados con el culto a los Lares.}

Los colegios religiosos romanos podían ser oficiales o semioficiales y privados; los primeros, encargados del culto público por el Estado, no nos interesan aquí. Los colegios religiosos privados son aquellos que, libremente, rinden culto a una divinidad por ellos escogida. Estos colegios existen desde época republicana y proliferaron mucho.

También se consideran colegios religiosos privados los formados por grupos que honran a los emperadores vivos o muertos, o a los Lares de una ciudad o de una persona importante, y están formados generalmente por gente humilde, fundamentalmente libertos y esclavos.

Las medidas restrictivas adoptadas por el Senado romano durante la época republicana en materia asociativa, excepto algunas restricciones de carácter particular, al parecer, solamente afectaron a Roma. Este estado de cosas, con mayor razón, se mantuvo en las provincias, donde las asociaciones no constituían peligro político alguno.

La situación de libertad asociativa en provincias cambió con la Lex Iulia de collegiis, que disolvió todos los colegios, salvo los tradicionales y legítimos. Desde este momento, todo colegio necesitaba una autorización estatal para constituirse. La aplicación de esta Ley en Roma se hizo inmediata, y después se extendió gradualmente a Italia y a las provincias.

Un tipo muy peculiar de colegios religiosos es el de los cultores Larum. Ya desde época republicana había asociaciones cuya finalidad era rendir culto a los Lares en unas aediculae que se colocaban en los cruces de las vías. WALTZING $(1968 ; 99)$ cree que estos colegios son exclusivamente funerarios, pero tienen también una finalidad cultural.

Estaban formados generalmente por esclavos y libertos que podían pertenecer a una familia o ser públicos. En el primer caso, se trata de colegios domésticos, y su finalidad es honrar a los Lares de esa familia. En el segundo se trata de familias públicas de esclavos y libertos que honran a los Lares públicos.

En Portugal, en Olisipo, hay un ejemplo de este tipo de colegios domésticos (CIL II 174): los cultores Larum Maliae Malioli, que hacen una dedicación a Esculapio Augusto. Este tipo de cultores Larum domésticos es muy frecuente en la epigrafía romana.

En Abdera, el liberto Suavis y el esclavo Faustus hacen una dedicación (CIL II 1980), a mediados del siglo I, a los Lares y al Genio. Las iniciales CCN son interpreta- 
das por Hübner como C(ultorum) C(ollegii) N... (nombre de una divinidad que se supone sería Némesis). M. Vigil indica que probablemente se trata de un colegio constituido en un fundo de un particular, con su vilicus (Faustus). La inscripción estaría dedicada a los Lares del propietario y al genio del fundo, y seguramente el nombre N... es el del propietario del mismo.

Un caso parecido de un colegio doméstico aparece en Ampurias, donde los cultores Larum de M. Cornelius Saturninus, edil, duumvir y flamen, le hacen una dedicación.

Hay también en Hispania colegios de cultores Larum publicorum: en Capera (CIL II 816; CIL II 817), los cultores Larum publicorum hacen una dedicación a su colega, el liberto Peculiaris, y otra a un desconocido, Albini filio, a su muerte; en Balsa (CIL II 4989) aparece una lista de amici curatores Larum.

El que estos cultores Larum publicorum deben considerarse como colegios está claro en la primera dedicación de Capera (CIL II 816), en que se emplea el término collega aplicado a uno de sus miembros. Su carácter funerario parece evidente en la segunda dedicación de Capera a un desconocido (CIL II 817), que es una lápida funeraria. Y, por último, su carácter religioso se muestra en la dedicación de Abdera a los Lares y al Genio cum aedicula (CIL II 1980).

Aparte de aquellas asociaciones cuya finalidad es exclusivamente religiosa, hay que señalar que todos los colegios romanos, del tipo que sean, a pesar de que su objetivo principal sea de otra clase, tienen siempre un carácter religioso, pues sus miembros se unen bajo la advocación de una divinidad.

Una inscripción hispana de interés en este sentido procede de Cartago Nova (CIL Suppl. 5929); en ella los piscatores et propolae de la ciudad hacen una dedicación, de pecunia sua, a los Lares Augustales et Mercurium.

No es demasiado abundante la epigrafía hispana que contiene datos sobre las divinidades adoradas por los colegios. Esto se debe a varias causas: primero, muchas inscripciones están incompletas, otras aluden a los colegios de forma indirecta, y otras son dedicaciones a emperadores, a patronos o personajes destacados, el resto son funerarias.

Hay que suponer que los colegios religiosos hispanos tendrían la misma organización que los del resto del Imperio, muy bien expuesta por WALTZING.

Los colegios formados por esclavos y libertos de familias ricas son los que se denominan cultores Larum y tienen un marcado carácter religioso, ya que adoran a los Lares de una familia, cuando se trata de colegios domésticos, o a los Lares públicos, si se trata de familias públicas.

Ya hemos hecho alusión a los ejemplos de cultores Larum domésticos en Olisipo y Ampurias, y cultores Larum publicorum: las dos inscripciones de Capera y de Balsa (CIL II 816; CIL II 817; CIL II 4989).

En ocasiones en estos colegios mixtos de esclavos y libertos aparecen también algunos ciudadanos libres. Este es el caso de la inscripción de Tavira (Balsa, en Lusitania) dedicada por unos amici curatores Larum que eran personajes libres. Hay que señalar la dedicación hecha por unos decuriones Larum que aparece en Tarraco (DRIT 166).

Tenemos que consignar aquí el gran número de inscripciones aparecidas en la $\mathrm{Pe}-$ nínsula Ibérica en que se alude a un magister Larum, que en la mayor parte de los casos es, al mismo tiempo, sevir augustalis. El número de estas inscripciones en que aparece mencionado un magister Larum es de diecisiete (no incluimos las inscripciones ya mencionadas que aluden a colegios).

Cinco de estos epígrafes proceden de la Bética: Corduba, Singilia Barba, Adamuz, Esparragosa de la Serna e Itálica (CIL II 2233; CIL II 2013; CIL II 2181; ILER 597; CIL II 1133); esta última es digna de una mención aparte, se trata de una lápida funeraria en memoria de $C$. Marcius Apilus, que fue al mismo tiempo magister Larum Augustorum y magister Genii Caesaris Augusti. 
Dos de las inscripciones proceden de Lucentum (Alicante) y de Cabeza del Griego (CIL II 3563; CIL II 3113). Los otros diez testimonios proceden de Tarraco o de lugares muy próximos a esta ciudad (CIL II 4293; CIL II 4297; CIL II 4304; CIL II 4306; CIL II 4082; CIL Suppl. 6106; DRIT 166; DRIT 429; DRIT 408; DRIT 425).

Este culto de los Lares Augusti, fundado por Augusto, se benefició de la restauración flavia. Permitió a las clases inferiores, esencialmente a los libertos, expresar su adhesión al soberano; es digno de mención el hecho de que, a partir de Trajano, los seviri son al mismo tiempo magistri Larum Augustorum, y que un liberto, L. Flavius Chrysogonus se cuenta entre ellos.

Por lo que se refiere al estudio de la onomástica de todos estos epígrafes, ésta parece indicar en la mayor parte de los casos una romanización muy profunda en los nombres de los dedicantes, que en su mayoría presentan los tria nomina latinos. En ciertos casos los dedicantes son libertos, ya hemos señalado que incluso uno de ellos era magistri Larum.

La preocupación fundamental de los emperadores, ya desde Augusto, fue no alejar a ninguna clase social de la religión oficial. Los colegios de los seviri augustales y los magistri Larum permiten resolver un problema importante: la integración en el culto imperial de los grupos que en la ciudad no gozan de todos los privilegios jurídicos, pero que cuentan socialmente por su papel económico.

El hecho de que los seviri augustales a partir de Trajano honren a los Lares Augusti y ostenten también el título de magistri Larum Augustorum no significa en absoluto que los colegios de los Lares Augusti daten todos de esta época y no se encuentren en otra. Esto sería muy raro, puesto que ya sabemos que los Lares están ligados a los orígenes mismos del culto imperial; desde el primer emperador los Lares privados de Augusto reciben un culto público.

Por último, de la distribución geográfica de todas estas dedicaciones se saca la conclusión interesante de que las menciones de magistri Larum y de colegios religiosos relacionados con el culto de los Lares están totalmente ausentes de la Lusitania y del Norte y Noroeste de la Península, situándose especialmente en la Bética y la Tarraconense, las regiones más romanizadas de la Península Ibérica.

Este hecho es significativo y coincide con lo que ya hemos mencionado en otras ocasiones: que este culto de los Lares Augusti, ligado íntimamente al culto imperial, se da sólo en las zonas más profundamente romanizadas. En cambio, en el Noroeste, es el culto de los Lares Viales el que realiza el papel de cohesión, ya que el culto imperial no cuajó en esta región de manera profunda.

\section{CONCLUSION.}

El primer hecho que llama poderosamente nuestra atención al realizar el análisis del culto a los Lares en la religión romana es la enorme amplitud de atribuciones que eran referidas a estas divinidades, que nos es demostrada muy claramente por los textos antiguos.

Este factor habría contribuido enormemente a facilitar su asimilación con deidades indígenas en las diversas zonas en las que los romanos se asentaron.

En el culto de los Lares en la Península Ibérica hay que hacer una diferenciación entre los Lares Viales, tópicos y gentilicios, por una parte, y los Lares romanos y augustos, por otra.

Los primeros esconden una realidad religiosa indígena. Resulta imposible saber con precisión si estos epítetos indígenas que acompañan a los Lares tópicos y gentilicios se refieren a una familia, a una comunidad o a un lugar geográfico concreto.

El área de localización geográfica del primer grupo de Lares que hemos distinguido coincide con la zona de Hispania en la que la romanización fue más tardía; no obs- 
tante, consideramos que esta romanización estuvo más presente de lo que se ha dicho hasta ahora.

Es cierto que existe en estas regiones una pervivencia indígena fortísima y que estas divinidades ocultan dioses indígenas, como lo indican los epítetos locales que se añaden al nombre romano de Lar, pero el hecho mismo de que las divinidades se asimilen a unos dioses romanos tan populares indica un conocimiento de estas deidades que demuestra que la romanización en estas zonas, aunque menor que en la Bética, no fue tan superficial y poco importante como se ha considerado.

Así pues, si los indígenas identificaron la divinidad romana con la local, es porque conocían los dioses romanos y comprendían las semejanzas existentes entre ambas entidades divinas.

El culto de los Lares más propiamente romanos y de los Lares augustos, ligados al culto imperial, presenta también una densidad importante, que quizás no se ha tenido en cuenta suficientemente.

La estructura de este culto de los Lares Augusti parece muy bien establecida; buena prueba de ello son las numerosas dedicaciones en que se alude a magistri Larum.

Destacan además las menciones de asociaciones de cultores Larum y decuriones Larum.

Los nombres de los dedicantes nos demuestran la importancia de los ciudadanos que podríamos llamar «de segunda categoría» en el culto de estos Lares relacionados con el culto imperial.

Hemos dejado en último lugar el culto de los Lares Viales porque es el que parece haber llamado más la atención de los estudiosos y porque su proporción en la Península Ibérica con respecto al resto del imperio romano resulta sorprendente.

Incluso si el contenido religioso de las dedicaciones a los Lares Viales sobrepasa muchas veces el simple papel de dioses protectores de los caminos, hay que considerar su presencia en función de ejes de caminos.

Esta relación entre las vías y las dedicaciones a los Lares Viales se ha podido establecer en la mayor parte de los casos; además, en este aspecto hay que tener en cuenta la gran obra constructora y reparadora de vías que fue llevada a cabo por los romanos en el Noroeste de la Península.

Los Lares Viales asumen un papel particular de cohesión, juntamente con Júpiter; este papel fue realizado en otras regiones más romanizadas por el culto imperial.

Las dedicaciones a estos Lares son abundantísimas con respecto a todo el resto del imperio romano, que en total presenta solamente cinco dedicaciones a estos dioses. Es significativo que unas divinidades tan populares en la religiosidad romana tengan tan pocos testimonios de devoción en todo el Imperio, contrastando de manera tan clara con la enorme abundancia del Noroeste peninsular.

Por último, hemos de señalar que, aunque no se puede negar de forma rotunda la hipótesis de la naturaleza céltica de los Lares Viales, puesto que no hay suficientes pruebas para ello, sí cabría al menos preguntarse si tiene una base lo suficientemente probada como para poder afirmarlo de manera tan categórica como han hecho muchos autores.

Hay que tener en cuenta que el celtismo de Galicia ha sido puesto en duda por algunos investigadores, que si bien admiten la presencia de etnias celtas en el área del Noroeste peninsular y su influencia en la cultura de la misma, sostienen, sin embargo, que lo genuino de esta cultura derivaba de una gran mezcla étnica de gentes asentadas en esta región desde la Edad del Bronce.

Además hay que considerar el hecho sorprendente de que otras zonas célticas como la Galia o Britania no presenten testimonios del culto a los Lares Viales.

Las formas que adoptan muchas de las dedicaciones a los Lares Viales son puramente romanas, por ejemplo, las aras de tres foci. 
La hipótesis que proponemos es la de considerar la influencia romana en este culto de los Lares Viales más importante de lo que se ha considerado hasta el momento.

No pretendemos olvidar el fondo indígena subyacente en este culto, pero no nos convence la afirmación tan asentada en la concepción tradicional de que esa realidad indígena sea una realidad religiosa de tipo céltico.

\section{ABREVIATURAS}

AEspA = Archivo Español de Arqueología.

AJA $\quad=$ American Journal of Archaeology.

ASEG = Arquivos do Seminario de Estudos Galegos.

BCPML = Boletín de la Comisión Provincial de Monumentos Históricos y Artísticos de Lugo.

Bol. Aur. $=$ Boletín Auriense.

Cl. Ph. = Classical Philology.

CEG = Cuadernos de Estudios Gallegos.

CRAI = Comptes Rendues de l'Académie des Inscriptions et Belles Lettres.

Hisp. Antiq. = Hispania Antiqua.

REA = Revue des Etudes Anciennes.

SA $\quad=$ Studia Archaeologica.

TAPA $=$ Transactions and Proceeding of the American Philological Association. 


\section{BIBLIOGRAFIA}

ACUÑA CASTROVIEJO, F. 1969-1970: «Nueva ara romana de Parga (Lugo)». BCPML, VIII, 223-227. 1971: «Los Lares en la Galicia romana». Actas do II Congresso Nacional de Arqueología. Coimbra. Vol. II, 353-357.

ADAMS HOLLAND, L. 1937: «The Shrine of the Lares Compitales». TAPA. LXVIII, 428-431.

ALARCÂO, J.-ETIENNE, R.-FABRE, G. 1969: «Le culte des Lares à Conimbriga». $C R A I, 213$ y ss.

ALBERTOS, M. L. 1952: «Nuevas divinidades de la antigua Hispania». Zephyrus. III, 49-63.

- 1956: «¿Mercurio, divinidad principal de los Celtas peninsulares?». Emerita. XXIV, 294-297.

- 1966: Onomástica primitiva de Hispania. Tarraconense y Bética. Salamanca.

- 1975: «Organizaciones suprafamiliares en la Hispania antigua». St. A. Valladolid.

- 1977: «Perduraciones indígenas en la Galicia romana: los castros, las divinidades y las organizaciones gentilicias en la epigrafía». Actas del Coloquio Internacional sobre el Bimilenario de Lugo. Lugo, 17-29.

ALFOLDY, G. 1975: Die Römischen Inschriften von Tarraco. Madrider Forschungen. Band 10.

ALMAGRO, M. 1966: Ampurias. Barcelona.

ARES VAZQUEZ, N. 1973: «Hallazgo de tres lápidas romanas». $B C P M L$, IX, 75-86.

ARES VAZQUEZ, N.-ARIAS VILAS, F.-DELGADO, X. 1979: «Unha ara aos Lares Viales no conxunto arqueolóxico de Termes (Carballedo, Lugo)». Bol. Aur. IX, 311-315.

ARIAS VILAS, F. 1973: «Novo achádego epigráfico nas murallas romanas de Lugo».CEG, XXVIII, 235243.

ARIAS VILAS, F. 1974: «La religión en la Galicia romana». Publicaciones del Liceo Franciscano. XXVII, 69-77.

ARIAS VILAS, F.-LE ROUX, P.-TRANOY, A. 1979: Inscriptions romaines de la province de Lugo. París. Diffusion de Boccard.

BAILEY, C. 1932: Phases in the Religion of Ancient Rome. London. Oxford University Press.

BALIL, A. 1973: «Algunos aspectos y problemas de la Galicia romana». CEG. XXVIII, 161-180.

BAYET, J. 1959: Histoire politique et psychologique de la religion romaine. París. Bibliothèque Historique.

BEAUJEU, J. 1976: "Cultes locaux et cultes d'Empire dans les provinces d'Occident aux trois premiers siècles de notre ère». Assimilation et résistance à la culture gréco-romaine dans le monde ancien. Travaux du VI. ${ }^{e}$ Congrès International d'Etudes Classiques. París, 440 y ss.

BELTRAN, A. 1976: Symposion de ciudades augusteas. I, 249-260.

BENNET PASCAL, C. 1964: «The Cults of Cisalpine Gaul». Latomus. LXXV.

BERMEJO BARRERA, J. C. 1978: La sociedad en la Galicia castreña. Santiago de Compostela. Follas Novas Edicións.

BLANCO FREIJEIRO, A. 1977: «El panteón romano de Lucus Augusti». Actas del Coloquio Internacional sobre el Bimilenario de Lugo. 107-123.

BLAZQUEZ, J. M. 1957: «Aportaciones al estudio de las religiones primitivas de España». AEspA. XXX, $52-53$.

- 1960: «El legado indoeuropeo en la Historia romana». Primer Symposium de Prehistoria de la Península Ibérica. Pamplona.

- 1970: «Las religiones indígenas del NO. de la Península Ibérica en relación con Roma». Legio VII Gemina. León, 65 y ss.

- 1971: «La Iberia de Estrabón». Hisp. Antiq. I, 11-94.

- 1975: Diccionario de las religiones prerromanas de Hispania. Madrid. Edic. Istmo.

BLAZQUEZ, J. M. 1976: «Rechazo y asimilación de la cultura romana en Hispania (siglos IV y V)». Assimilation et résistance à la culture greco-romaine dans le monde ancien. Travaux $d u V I .{ }^{e}$ Congrès International d'Études Classiques. París.

- 1977: «La romanización del NO. de la Península Ibérica». Actas del Coloquio Internacional sobre el Bimilenario de Lugo. 67-83.

BOSCH-GIMPERA, P. 1932: Etnología de la Península Ibérica. Barcelona.

- 1939: «Two Celtic Waves in Spain». Proceedings of the British Academy. XXVI. London.

- 1950: «Infiltraçoês germánicas entre os Celtas peninsulares». Rev. de Gimarâes. LX, 339-349.

BOYCE, G. K. 1937: «Corpus of the Lararia of Pompeii». Memoirs of the American Academy in Rome. XIV.

BULARD, M. 1926: «La religion domestique dans la colonie italienne de Délos d'après les peintures murales et les autels historiés». Bibliothèque des Ecoles françaises d'Athènes et de Rome. CXXXI. París.

CARDOZO, M. 1965: «A romaniçao do Noroeste da Península Hispanica». Ethnos. IV, 75-82.

CARO BAROJA, J. 1943: Los pueblos del Norte de la Península Ibérica. Madrid.

- 1957: España primitiva y romana. Barcelona.

CARTER, J. B. 1906: The religion of Numa. London. 
CAVADA NIETO, M. 1981: «Nuevas aras romanas de la provincia de Orense». Primera reunión gallega de estudios clásicos. Santiago de Compostela. 152-158.

CLEBERT, J. P. 1970: Provence antique. II: L'époque gallo-romaine. París. Ed. Robert Laffont.

COLLINGWOOD, R. 1969: The Archaeology of Roman Britain. Oxford.

DARBY NOCK, A. 1972: Essays on Religion and the Ancient World. I. Oxford. Clarendon Press.

DELATTE, L. 1937: «Recherches sur quelques fêtes mobiles du calendrier romain». L'Antiquité classique. VI.

D’ENCARNAÇAO, J. 1972: «Vestigios do culto dos Lares em territorio portugués». Rev. de Gimarâes. LXXXII, 91-105.

- 1975: Divinidades indigenas sob o dominio romano em Portugal. Lisboa.

D'ORS, A. 1942: «Sobre los orígenes del culto al emperador en la España romana». Emerita. X, 197-227.

DUMEZIL, G. 1961: "Quaestiunculae Indo-Italicae, 8-10». Latomus. XX, 262-265.

- 1966: La religion romaine archä̈que. París. Payot.

DUVAL, P. M. 1952: La vie quotidienne en Gaule pendant la paix romaine. París. Librairie Hachette.

- 1957: Les dieux de la Gaule. París. Presses Universitaires de France.

ELORZA, J. C. 1967: Ensayo topográfico de epigrafía alavesa. Vitoria.

1972: La romanización del País Vasco. Bilbao.

ETIENNE, R. 1958: «Le culte impérial dans la Péninsule Ibérique d'Auguste à Dioclétien». Bibliothèque des Ecoles Françaises d'Athènes et de Rome. París.

- 1973: «Les syncrétismes religieux dans las Péninsule Ibérique à l'époque impériale». Les syncrétismes dans les religions grecque et romaine. (Colloque de Strasbourg 9-11 juin 1971). 153163.

ETIENNE, R.-FABRE, G.-LE ROUX, P.-TRANOY, A. 1976: «Les dimensions sociales de la romanisation en la Péninsule Ibérique des origines à la fin de l'Empire». Assimilation et résistance à la culture gréco-romaine dans le monde ancien. Travaux de VI. ${ }^{e}$ Congrès International d'Etudes Classiques. París. 440 y ss.

GARCIA Y BELLIDO, A. 1947: «Estudios sobre escultura romana en los museos de España y Portugal». Revista de Archivos, Bibliotecas y Museos. LIII.

- 1949: Esculturas romanas de España y Portugal. Madrid.

- 1950: «Cuatro esculturas romanas inéditas del Museo Arqueológico de Sevilla». AEspA. LXXXI, 361-371.

- 1959: «Las colonias romanas de Hispania». Anuario de Historia del Derecho Español. XXIX, 447-512.

1966-67: «La latinización de España». AEspA. XXXIX-XL, 3-30.

GIL, L. 1969: Therapeia. La medicina popular en el mundo clásico. Madrid.

GORGES, J. 1979: Les villes de la Péninsule Ibérique. París. Diffusion de Boccard.

GRENIER, A. 1945: La Gaule Celtique. Toulouse. Didier.

- 1945: Les Gaulois. Bibliothèque Historique. París. Payot.

1946: La Gaule. Province romaine. Toulouse. Didier.

HARMON, D. P. 1978: "The Family Festivals of Rome». Aufstieg und Niedergang der Römischen Welt. Band II, 16,2. 1592-1603.

HATT, J. J. 1965: «Essai sur l'évolution de la religion gauloise». REA. LXVII, 80 y ss.

1970: Histoire de la Gaule romaine (120 av. J. C.-451 apr. J. C.). París. Payot.

KRUTA, V. 1977: Los Celtas. Madrid. Colec. Edaf Universitaria.

LAING, G. J. 1921: "The Origin of the Cult of the Lares». Cl. Ph. XVI.

- 1963: Survivals of Roman Religion. New York. Cooper Square Publishers.

LAMBRINO, S. 1965: «Les cultes indigènes en Espagne sous Trajan et Hadrien». Les empereurs romains de l'Espagne. Colloques Internationaux du Centre National de la recherche scientifique. París.

LEITE DE VASCONCELOS, J. 1905: Religiôes da Lusitania. 3 vols.

LE ROUX, P.-TRANOY, A. 1973: «Notes d'épigraphie romaine de Galice». CEG, XXVIII, 221-234.

- 1973: «Rome et les indigènes dans le nord-ouest de la Péninsule Ibérique. Problèmes d'épigraphie et d'histoire». Mélanges de la Casa de Velázquez. IX, 177-231.

- 1974: «Contribution à l'étude des régions rurales du NO. hispanique au Haut Empire: deux inscriptions de Penafiel». Actas do III Congresso Nacional de Arqueología. Vol. I. Porto, 249-258.

LIEBESCHUETZ, J. H. W. G. 1979: Continuity and Change in Roman Religion. Oxford. Clarendon Press. LIVERSIDGE, J. 1968: Britain in the Roman Empire. London. Routledge and Kegan Paul.

LOPEZ CUEVILLAS, F. 1934: "Estudos sobre a Edade do Ferro do noroeste da Peninsula. A relixion». ASEG. VI, 295 y ss.

- 1953: La civilización céltica en Galicia. Santiago de Compostela.

- 1958: «Lápidas romanas de la provincia de Orense». CEG. XIII, 343-358. 
LORENZO, J.-D’ORS, A. 1961: «Inscripciones romanas de Galicia. IV: Provincia de Orense». CEG. L, 267 y ss.

LORENZO, J.-BOUZA BREY, F. 1965: «Inscripciones romanas votivas de la provincia de Orense». CEG. LXII, 261 y ss.

MALUQUER DE MOTES, J. 1954: «Los pueblos de la España Céltica». Historia de España, dirigida por Menéndez Pidal. T. I, vol. III. Madrid.

MARINER, S. 1973: Inscripciones romanas de Barcino. Barcelona.

MESLIN, M. 1969: «Persistances païennes en Galice vers la fin du VI.e siècle». Hommages à Marcel Renard. II. Bruxelles, 512-524.

MOCSY, A. 1974: Pannonia and Upper Moesia. A History of the Middle Danube Provinces of the Roman Empire. London. Routeledge and Kegan Paul.

NILSSON, M. P. 1954: «Roman and Greek Domestic Cult». Opuscula Romana. Vol. I, 77-85.

ORR, D. G. 1978: «Roman Domestic Religion: The Evidence of the Household Shrines». Aufstieg und Niedergang der Römischen Welt. Band II, 16, 2, 1557-1591.

OTERO PEDRAYO, R. 1980: Historia de Galiza. Dirigida por...

PETERSON, R. M. 1919: "The Cults of Campania». Papers and Monographs of the American Academy in Rome. I.

PICARD, R. 1923: Marbres antiques du Musée du Prado à Madrid. Bordeaux.

PICCALUGA, G. 1965: Elementi spettacolari nei rituali festivi romani. Roma. Edizioni dell'Ateneo.

POULSEN, F. 1933: Sculptures antiques des musées de province espagnols. Copenhague.

POWELL, T. G. E. 1965: «Os Celtas». Primero volume da colecçâo Historia mundi. Lisboa. Edit. Verbo.

RINCON, M. A. 1970: «Consideraciones generales acerca de la romanización de las tribus galaicas». Pyrenae. VI, 71-77.

RIVAS FERNANDEZ, J. C. 1972: «La capilla de San Xiao de Fontefría y su ara votiva a los Lares Viales». Bol. Aur. II, 303 y ss.

1973: «Nuevas aras romanas orensanas». Bol. Aur. III, 57-96.

RIVERO, C. M. 1927: Los bronces antiguos del Museo Arqueológico Nacional. Primera parte: Figuras. Toledo.

RODRIGUEZ COLMENERO, A. 1972: «Sobre los pueblos prerromanos del sur de Galicia». Bol. Aur. II, 193-240.

1973: «Epígrafes inéditos de tierras orensanas». Durius. I, 361-366.

- 1977: Galicia meridional romana. Univ. de Deusto.

ROLDAN, J. M. 1972: «El elemento indígena en las guerras civiles en Hispania. Aspectos sociales». Hisp. Antiq. II, 77-123.

ROSS TAYLOR, L. 1914: «Augustales, Seviri Augustales and Seviri: a Chronological Study». TAPA. XLV, 231-235.

- 1925: «The Mother of the Lares». AJA. XXIX, 299-313.

SALWAY, P. 1981: Roman Britain. Oxford. Clarendon Press.

SANTERO, J. M. 1978: Asociaciones populares en Hispania romana. Publicaciones de la Universidad de Sevilla.

SCHILlING, R. 1979: Rites, cultes, dieux de Rome. Etudes et commentaires. 92. París. Editions Klimcksieck.

SJOESTEDT, M. L. 1949: Gods and Heroes of the Celts. London. Methuen and Co.

TABOADA CHIVITE, J. 1975: «La encrucijada en el folklore de Galicia». Bol. Aur. V, 101-112.

1976: «Nuevos testimonios del culto a los Lares Viales en la Gallaecia». Gallaecia. II, 193-200.

THEVENOT, E. 1948: Les Gallo-Romains. Coll. «Que sais-je?». París. Presses Universitaires de France. 1949: Histoire des Gaulois. Coll. «Que sais-je?». París. Presses Universitaires de France.

- 1968: Divinités et sanctuaires de la Gaule. París. Fayard.

THOUVENOT, R. 1927: Catalogue des figurines et objets de bronze du Musée Archéologique de Madrid. París.

TORRES RODRIGUEZ, C . 1952: «El culto al emperador en Galicia». CEG. VII, 197-230.

TOUTAIN, J. Les cultes païens dans l'Empire romain. 3 vols. París. Bibliothèque de l'Ecole des Hautes Etudes. XX.

TOVAR, A.-NAVASCUES, J. M. de. 1950: «Algunas consideraciones sobre los nombres de divinidades del Oeste peninsular». Miscelánea en memoria de Francisco Adolfo Coelho. Lisboa.

TRANOY, A. 1980: «Religion et societé à Bracara Augusta au Haut Empire romain». Actas do Seminario de Arqueología do Noroeste peninsular, 67 y ss. Gimarâes.

- 1981: La Galice romaine. Recherches sur le nord-ouest de la Péninsule Ibérique dans la Antiquité. París. Diffusion de Boccard.

- 1981: «Romanisation et monde indigène dans la Galice antique: problèmes et perspectives». Primera reunión gallega de estudios clásicos. 105 y ss. Santiago de Compostela.

VARIOS AUTORES. 1979: Prehistoria e Arqueoloxía de Galicia. Estado da cuestión. Sección de Arqueoloxía e Prehistoria do Instituto de Estudos Galegos «Padre Sarmiento». Lugo. 
VARIOS AUTORES. 1980: The Archaeology of Roman Pannonia. Budapest. The University Press of Kentucky. Akadémiai Kiadó.

VIVES, J. 1971: Inscripciones latinas de la España romana. Barcelona.

VRIES, J. de. 1975: La réligion des Celtes. París. Payot.

WAITES, M. 1920: «The Nature of the Lares and their Representation in Roman Art». AJA. XXIV, 241261.

WALTZING, J. P. 1968: Etude historique sur les corporations professionnelles chez les Romains depuis les origines jusqu'à la chute de l'Empire d’Occident. 4 vols. Roma. «L'Erma» di Bretschneider. 